\title{
The Horizontal Effect of International Human Rights Law in Practice
}

\section{A Comparative Analysis of the General Comments and Jurisprudence of Selected United Nations Human Rights Treaty Monitoring Bodies}

\section{Lottie Lane}

Ph.D. Candidate, Endowed Chair Groningen Centre for Law and Governance c.l.lane@rug.nl

\begin{abstract}
This article critically examines whether, and how, five United Nations human rights treaty monitoring bodies deal with situations in which human rights have been interfered with by non-State actors. The article uses the concepts of 'direct' and 'indirect' horizontal effect of international human rights law. An in-depth comparative analysis reviews the monitoring bodies' general comments and views on individual communications from the bodies' establishment until August 2017. The analysis identifies very limited evidence of 'direct', and two main kinds of 'indirect' horizontal effect of human rights applied by the bodies. First, it finds that while the bodies do engage with the ways in which non-State actors can interfere with human rights, they predominantly focus on the positive and procedural obligations of States. Second, it finds that where non-State actors are sufficiently 'State-like' in their nature and actions, they may be recategorised as public actors for the purposes of human rights.
\end{abstract}

\section{Keywords}

international human rights law - non-State actors - horizontal effect - obligation to protect - UN human rights treaty monitoring bodies 
According to the prevalent approach in legal science, the responsibility for protecting individuals' human rights lies in the positive (vertical) obligations of the State. Non-State actors are to be regulated and controlled by the State through its domestic legal system. However, many non-State actors are in a position to greatly affect individuals' enjoyment of their human rights. ${ }^{1}$ This is particularly true of non-State entities carrying out public functions, having control over an area of territory or even being in a position to direct States in the adoption and implementation of certain domestic laws and policies. However, single individuals may also be in a position of relative power over (for example) other family members, employees, or members of a different social class, placing them in a position to more easily affect another individual's rights.

The traditional human rights paradigm in the international legal discourse was founded on a relationship of dependence and trust on behalf of individuals towards States as the primary subjects of international law ${ }^{2}$; human rights provided them with 'fundamental guarantees and standards of legal protection' against potential abuses of State power. ${ }^{3}$ The focus of international human rights law has therefore been on the actions of States; private actors would normally fall within the remit of domestic criminal laws ${ }^{4}$ or private

1 Throughout this article, the term 'non-State actor' is used synonymously with 'private actor' to refer generally to all actors that are not classified as 'State actors'. This is a very broad definition, as it also includes private actors such as individuals. See E. van Schagen, 'Source of Concern or Room for Experimentation? Private Autonomy in the Development of Alternative Regulation in German and Dutch Private Law', European Journal of Comparative Law and Governance 3 (2016) 187 at 188. In situations within the present article regarding particular non-State actors, the specific actor is identified.

2 Reflected in the fact that States 'possess the totality of international rights and duties recognized by international law'. See International Court of Justice, Reparations for Injuries Suffered in the Service of the United Nations, Advisory Opinion of April 11, 1949, ICJ Reports 1949, 174, para. 180.

3 A. Reinisch, 'The Changing International Legal Framework for Dealing with Non-State Actors', in: P. Alston (ed) Non-State Actors and Human Rights (Oxford: Oxford University Press, 2005) 37 at 38.

4 See N. Rodley, 'The Evolution of the International Prohibition of Torture', in Amnesty International, 'The Universal Declaration of Human Rights 1948-1988: Human Rights, the UN and Amnesty International', 63, cited in C. McGlynn, 'Rape, Torture and the European Convention on Human Rights', International and Comparative Law Quarterly $5^{8}$ (2009) 565 at 594. 
laws, ${ }^{5}$ rendering international governance of their actions unnecessary. Nevertheless, the 'new-medievalism' of international relations ${ }^{6}$ is steadily replacing the Westphalian, one-dimensional State-centric model of the international legal order with a multi-layered system. ${ }^{7}$ As a by-product of globalisation, this is creating a 'neo-feudal' society in which power and influence are distributed amongst various actors. ${ }^{8}$ But States, originally targeted for obligations because of their socio-economic and legal power monopoly over individuals 'in the absence of legal restraints, ${ }^{9}$ are continuously losing ground to private actors. ${ }^{10}$ It is increasingly evident that despite trusting States to protect individuals from interference with their rights by third parties, domestic laws are not (always) sufficient or effective in governing the actions of non-State actors vis-à-vis human rights. ${ }^{11}$

This encroachment of non-State actors is not confined to practical effects; whilst under the current legal framework the State remains the primary actor,

5 Many limits on the permitted actions of private persons can be found, for example, in the fields of domestic tort law and domestic contract law. The interpretation and application of domestic private law between private parties has for some time also included human rights elements, which has been the subject of much academic discussion. See below, footnotes 38 and 39 .

6 H. Bull, The Anarchical Society: A study of order in world politics, $\left(\mathrm{1}^{\text {st }}\right.$ edn, New York: Columbia University Press, 1977) 281, discussed in J. Elias and P. Sutch, International Relations: The Basics (London: Routledge, 2007) 103-104.

7 For discussion on the fragmentation of international law into different (and conflicting) regimes, see e.g. A. Fischer-Lescano and G. Teubner, 'Regime Collisions: The Vain Search for Legal Unity in the Fragmentation of Global Law', Michigan Journal of International Law 25(4) (2004) 999.

8 K. Raustiala, 'The Architecture of International Cooperation: Transgovernmental Networks and the Future of International Law', Virginia Journal of International Law 43(1) (2002) 1 at 2 .

9 F. Raday, 'Privatising Human Rights and the Abuse of Power', Canadian Journal of Law and Jurisprudence 13 (2000) 103 at 108-110, cited in J.A. Hessbruegge, 'Human Rights Violations Arising from Conduct of Non-State Actors', Buffalo Human Rights Law Review 11 (2005) 21 at 26 .

$10 \quad$ For example, multinational corporations - see e.g. J.L.J. Hazenberg, 'Transnational Corporations and Human Rights Duties: Perfect and Imperfect', Human Rights Review 17(4) (2016) 479 .

11 This is particularly the case when transnational private actors are concerned. As Gunther Teubner points out, " $[\mathrm{i}] \mathrm{n}$ the global context, the State influence on private actors is more indirect, more distant', and it becomes harder to hold States responsible for the actions of private parties (under the doctrine of 'indirect horizontal effect' - see below, Section 3.3). G. Teubner, 'The Anonymous Matrix: Human Rights Violations by "Private” Transnational Actors', The Modern Law Review 69(3) (2006) 327 at 329. 
some non-State actors have now obtained a certain political or even a 'lawmaking' role. ${ }^{12}$ States are no longer the only actors adopting instruments aimed at implementing or developing international law (including aspects of international human rights law). Non-State actors are becoming increasingly involved in global governance, ${ }^{13}$ whether through contributions to international law itself, or through (self-)regulation by private bodies. ${ }^{14}$ As a result, non-State actors are beginning to entrench themselves in the international human rights regime. Non-State actors are also becoming increasingly entrenched in the regime by other actors, including scholars and civil society. For example, there now exist many studies, projects and initiatives examining the ways in which non-State actors could be held accountable for interfering with the enjoyment of human rights. ${ }^{15}$ There are also more and more non-legally binding instruments being adopted, including by the UN itself, to encourage non-State actors to respect human rights and States to more rigorously regulate non-State actors (a popular example being the UN Guiding Principles on Business and Human Rights $\left.{ }^{16}\right)$. Furthermore, international human rights treaty monitoring bodies have found themselves faced with many cases in which the direct causal

This term is used here cautiously, to represent the contributions that many non-State actors make towards the drafting process of both binding and non-binding instruments (i.e. 'hard' and 'soft' international human rights law). For a discussion of the role of private parties in the development of binding and non-binding rules, see van Schagen, 'Source of Concern or Room for Experimentation?' (n 1$)$.

13 See J. d'Aspremont, 'International Law-Making by Non-State Actors: Changing the Model or Putting the Phenomenon into Perspective?', in: M. Noortmann and C. Ryngaert (eds) Non-State Actor Dynamics in International Law: From Law Taking to Law Making? (Ashgate Publishing Group: Surrey, 2010), 171-194.

14 As Yannis Papadopoulos has noted, '[a] plethora of non-state and sector-specific governance arrangements have been established' on a transnational level, emerging particularly since the 1980 s. See Y. Papadopoulos, 'The challenge of transnational private governance: Evaluating authorization, representation, and accountability', Laboratoire interdisciplinaire d'évaluation des politiques publiques Working Paper No. 8 (2013) 1.

15 See e.g. P. Alston (ed) Non-State Actors and Human Rights (Oxford: Oxford University Press, 2005); University of Antwerp, 'About GLOThro'. Retrieved 18 October 2017, www .uantwerpen.be/en/projects/glothro/about-us/, which involved extensive research on the human rights obligations of non-State actors; and J. D'Aspremont et al., 'Sharing Responsibility Between Non-State Actors and States in International Law: Introduction', Netherlands International Law Review 62(1) (2015) 49, which forms part of a collection of articles on 'Organized Non-State Actors'.

16 See un Human Rights Council, 'Report of the Special Representative of the SecretaryGeneral on the issue of human rights and transnational corporations and other business enterprises: Guiding Principles on Business and Human Rights: Implementing the 
responsibility for harm to human rights lies with a non-State actor, rather than a State. ${ }^{17}$ In these cases, the supervisory bodies have often interpreted and applied human rights standards vis-à-vis non-State actors (see Section 4).

A major question within the field of international human rights law is whether the answer to human rights interference by non-State actors should be addressed through the international legal framework, or whether non-legal approaches would better protect individuals. In other words, do we need to look beyond the current (albeit still developing) legal framework to achieve de facto horizontal effect? In order to answer this question, it is necessary to have a very thorough understanding of how the current international human rights law system deals with non-State actors. This of course requires an examination of international human rights obligations per se, international human rights treaties, and the application of these treaties in practice. This article undertakes a comparative analysis of the latter, focusing on the interpretation and application of human rights vis-à-vis non-State actors by five core United Nations human rights treaties supervisory bodies. The analysis examines and compares the different ways in which the five monitoring bodies deal with situations and cases where the harm to an individual's human rights was directly caused by a non-State actor. The analysis produces two main results: (1) identification of whether (and if so, which) different kinds of horizontal effect are employed by the monitoring bodies; and (2) identification of whether (and if so, how) the monitoring bodies apply the types of horizontal effect differently to distinct kinds of non-State actors (e.g. individuals, private companies and non-State armed groups).

Before moving on to the methodology of the article, a quick note must be made regarding its place in academic literature. Much research has already been conducted into the 'horizontal effect' of international human rights law; indeed, a veritable abundance of literature can already be found on 'non-State actors and human rights. ${ }^{18}$ The present article uses much of this literature in setting out its theoretical framework, particularly that regarding the direct

United Nations "Protect, Respect and Remedy" Framework' (21 March 2011) A/HRC/17/31 (UNGPS).

17 See Sections 4.1.2, 4.2.2, 4.3.2, 4.4.2 and 4.5.2, below.

18 See, for example, D. Murray, Human Rights Obligations of Non-State Armed Groups (Oxford: Hart Publishing, 2016); N.C. Santarelli, 'Non-State Actor's Human Rights Obligations and Responsibility under International Law', Revista Electrònica de estudios internacionales 15 (2008); A. Hallo de Wolf, Reconciling Privatization with Human Rights (Antwerp: Intersentia, 2011); A. Clapham, Human Rights Obligations of Non-State Actors (Oxford: Oxford University Press, 2006). 
and indirect horizontal effect of human rights and the typology of States' obligations.

Some scholars, most notably Andrew Clapham, have published analyses of horizontal effect at the international level. ${ }^{19}$ The present article seeks to both draw and build upon such literature, conducting a more thorough analysis in the practice of international human rights monitoring bodies. Clapham's seminal book on 'Human Rights Obligations of Non-State Actors', published in 2006, includes a chapter on 'Selected human rights treaties'. ${ }^{20}$ The chapter takes the treaties themselves as a starting point, looking into several pertinent examples of general comments and individual complaints that deal with the interpretation and application of the six treaties he analyses. However, a more comprehensive and systematic (as well as up-to-date) analysis of the general comments and cases from human rights monitoring bodies has yet to be carried out. The present article seeks to fill this gap.

2

\section{Research Methods and Design}

The article examines the ways in which the United Nations human rights treaty monitoring bodies established in connection to five 'core' United Nations human rights treaties, have interpreted and applied human rights obligations in relation to non-State actors. Generally speaking, the bodies express their interpretations of various provisions of the respective human rights treaties through 'general comments' 21 and apply the provisions through their respective individual complaints procedures, in the form of 'views' (see below). General comments are one of the most well-known outputs of human rights treaty bodies. While the source of Committees' mandates may differ, ${ }^{22}$ the adoption

19 Clapham, Human Rights Obligations of Non-State Actors (n 18).

$20 \quad$ Ibid $317-346$.

21 Sometimes known as General Recommendations.

22 Most treaty bodies are given the mandate to provide general comments, or general recommendations through the 'core' human rights treaty itself (see, for example, Article 4o(4) International Covenant on Civil and Political Rights, which allows the Human Rights Committee to 'transmit ... such general comments as it may consider appropriate, to the States Parties' (see UN Office of the High Commissioner for Human Rights (OHCHR). 2005. 'Civil and Political Rights: The Human Rights Committee' Factsheet No. 15 (Rev.1) 24. Retrieved 18 October 2017 www.ohchr.org/Documents/Publications/FactSheet15rev.1en. pdf)). An exception to this is the UN Committee on Economic, Social and Cultural Rights (CteeESCR, discussed below), which was not established until after the entry into force 
of general comments is a common practice of each of the bodies examined. ${ }^{23}$ General comments and views of the treaty bodies are not legally binding, ${ }^{24}$ but have been repeatedly found to be of high interpretative value. ${ }^{25}$ Not every State Party to the treaties takes this approach towards general comments and views. ${ }^{26}$ This does not negate their importance for the task at hand, however; the outputs of the bodies remain very important for determining how, at the international level the horizontal effect of human rights is (whether implicitly or explicitly) discussed and applied.

Views of the Committees regarding individual complaints are adopted by virtue of the individual complaints/communications procedures for each of the bodies examined. For the most part, the authority to hear individual complaints derives not from the main human rights treaty itself, but from an additional (and optional) protocol. ${ }^{27}$ There is no system of precedence within the jurisprudence of the treaty bodies, which means that the scope and application of rights may change over time and the impact of the decisions could

of the Covenant on Economic, Social and Cultural Rights (see UN CteeESCR, 'Rules of Procedure of the Committee', E/C.12/199o/Rev.1 (1990), Rule 65).

23 The UN OHCHR provides documents compiling the majority of general comments of all treaty bodies, the individual general comments of which may be found on the website of each body. See Un OHCHR, 'Human Rights Treaty Bodies - General Comments'. Retrieved 18 October 2017 www.ohchr.org/EN/HRBodies/Pages/TBGeneralComments.aspx.

24 This view has been upheld, for example, by the Spanish Constitutional Court and the Irish Supreme Court. The latter Court found that although the decisions of treaty bodies are authoritative, their non-binding nature was supported by the fact that 'neither the Covenant nor the Committee at any point purports to give any binding effect to the views expressed by the Committee' (referring to the Human Rights Committee). See sTC 70/2002, 3 April 2002, para. 7; and Kavanagh v. Governor of Mountjoy Prison, [2002] IESC 11 (1 March 2002), respectively, both cited in the International Law Association Committee on International Human Rights Law and Practice, 'Berlin Conference Report', 71st International Law Association Conference Report (2004).

25 For examples, see Essex Autonomy Project, 2014. 'Research Note: The Legal Status of General Comments', 2. Retrieved 18 October 2017 http://autonomy.essex.ac.uk/wp-content/ uploads/2014/07/Legal-status-of-General-Comments-.pdf.

$26 \quad$ Ibid.

27 For example, the authority for the Committee on the Elimination of Discrimination against Women (CteeEDAW) to hear individual communications comes from the UN General Assembly, 'Optional Protocol to the Convention on the Elimination of All Forms of Discrimination Against Women', 6 October 1999, United Nations, Treaty Series vol. 2131,83 . 
be affected. ${ }^{28}$ As with general comments, the Committees' views are not legally binding, although they have been said to be of 'great weight' because the bodies are 'established specifically to supervise the application' of the relevant treaties. $^{29}$

The following analysis looks at general comments from the establishment of the treaty bodies until August 2017, and views on individual complaints from the time of activation of the individual complaints procedures until $\mathrm{Au}$ gust 2017.

The monitoring bodies chosen for the analysis are: (1) the Human Rights Committee; (2) the Committee on Economic, Social and Cultural Rights; (3) the Committee on the Elimination of Discrimination against Women; (4) the Committee against Torture; and (5) the Committee on the Elimination of all Forms of Racial Discrimination. Although by now there are nine 'core' human rights treaties, ${ }^{30}$ the five monitoring bodies examined were chosen for analysis due to their substantive contributions in the context of non-State actors and human rights obligations and on the nature of human rights obligations more generally (see, e.g. the Committee on Economic, Social and Cultural Rights ${ }^{31}$ ). Further, the Human Rights Committee and the Committee on Economic, Social and Cultural Rights were chosen for the reason that they supervise the implementation of the 'twin' human rights Covenants - the International Covenant on Civil and Political Rights and the International Covenant on Economic, Social and Cultural Rights. The Covenants were adopted at the same time, in

28 While the use of the term 'jurisprudence' may be controversial when referring to the views of the monitoring bodies (as they are indeed neither courts, nor bodies with legally binding authority), this is the term used by the UN OHCHR itself, and is sometimes used in this article.

29 These comments were made by the International Court of Justice in relation to the Human Rights Committee (HRCtee) in the case of Ahmadou Sadio Diallo (Republic of Guinea v. Democratic Republic of Congo), ICJ Reports (2010-II) 692. See G. Ulfstein, 'Law-Making by Human Rights Treaty Bodies', in: R. Liivoja and J. Petman (eds) International Law-making. Essays in Honour of Jan Klabbers (London: Routledge, 2014) 249. The comments can be extended by analogy to relate to the jurisprudence of each of the treaty bodies, which some scholars maintain are binding 'in effect' regardless of their formal status. See for discussion G. Ulfstein, 'Individual Complaints', in: H. Keller and G. Ulfstein (eds) UN Human Rights Treaty Bodies: Law and Legitimacy (Cambridge: Cambridge University Press, 2012) 73 at 92-94.

30 See UN онснR, 'The Core International Human Rights Instruments and their Monitoring Bodies'. Retrieved 18 October 2017 www.ohchr.org/EN/ProfessionalInterest/Pages/CoreInstruments.aspx.

31 Un CteeESCR, 'General Comment No. 3: The Nature of States Parties' Obligations (Art. 2, Para. 1, of the Covenant)', 14 December 1990, E/1991/23. 
1966, and laid down what was then the full range of international human rights. The Committee on the Elimination of Discrimination against Women was chosen as a good example of bodies that monitor human rights treaties drafted and adopted for the protection of a particular vulnerable group - in this case, women. ${ }^{32}$ Finally, the Committee against Torture and the Committee on the Elimination of all Forms of Racial Discrimination were chosen as examples of bodies that monitor the implementation of subject-specific human rights treaties - the subjects here being torture and racial discrimination. Including this range of bodies in the analysis should allow for a broad understanding of how horizontal effect is applied in practice within the international human rights system. For reasons of space, the output of the monitoring bodies in relation to State reporting procedures (i.e. concluding observations) have been excluded from the analysis in this article. The sheer volume of concluding observations makes it impractical to analyse them within the framework of this article, and the results obtained from the general comments and views of the Committees are considered to be substantive enough without the analysis of additional documents.

The examples analysed in the following sections were found using two different methods. First, a database compiled by scholars, 'Bayefsky', was relied upon, which aims to 'enhanc[e] the implementation of the human rights legal standards of the United Nations'. ${ }^{33}$ The database includes a large collection of documents containing references to particular subject-matters in the supervisory bodies' application of human rights treaties. The document relied upon for this article lists (and contains extracts of) which general comments and views of the bodies include reference to 'Public and Private Actors' ${ }^{34}$ The document was used as a starting point to identify which general comments and individual communications would be relevant for the analysis. Each general comment or communication identified in the Bayefsky document was then searched manually, using the terms 'non-State actor', 'private actor', and 'positive obligations'. Where this led to information regarding how the relevant monitoring body viewed or applied human rights obligations vis-à-vis non-State actors,

32 Another vulnerable group protected by a UN human rights treaty is children. An analysis of the Convention on the Rights of the Child (as well as a discussion of several other international human rights instruments), in light of theories on the horizontal effect of human rights has been conducted by Nuno Ferreira. See N. Ferreira, Fundamental Rights and Private Law in Europe: The case of tort law and children (Routledge: London, 2011) 121.

33 Bayefsky, 'The United Nations Human Rights Treaties'. Retrieved 18 October 2017 www .bayefsky.com.

34 Bayefsky, 'Public and Private Actors - General'. Retrieved 18 October 2017 www.bayefsky .com//themes/public_general_general-comments.pdf. 
the general comment or individual communication was used in the analysis. In some cases, however, the reference was cursory and was not substantive or informative enough to contribute to the analysis, and was therefore excluded from the analysis. Although extensive, the database is not exhaustive as it does not include general comments and views after 2005. For this reason, the individual general comments and jurisprudence of the relevant bodies from 2005-2017 were manually searched using the three terms above, to identify any new references to non-State actors. This search was conducted using the Office of the High Commissioner for Human Rights' treaty body database. ${ }^{35}$ Given the nature of this method, it is possible that some views or general comments that have a less explicit (but perhaps still substantive) reference to non-State actors may have been missed. Nevertheless, it is believed that the documents discussed provide enough material to gain an overview of the way in which each of the five bodies deal with the horizontal effect of human rights.

The analysis itself was conducted from the viewpoint of 'horizontal effect', and due to the findings, turned out to be exclusively focused on indirect horizontal effect. In particular, the State obligation to protect human rights (and the encompassed duty of due diligence) are frequently referred to in the analysis as a starting point (see Section 3.3). Other than this, the analysis has been made as 'clean' as possible, referring as far as possible to the language of the monitoring body itself, reserving any categorisation of the type of approach used until the reflective comments in Section 5 .

The article begins with an explanation of the theoretical framework within which the analysis was undertaken (Part 3), explaining in particular the concept of horizontal effect. From there, the analysis proper begins (Part 4), which is structured by monitoring body. First, a Committee's general comments are examined, before moving on to the Committee's 'views'. Brief critical reflections on the practice of each body are made before moving on to the next monitoring body. Part 5 constitutes the article's comparative analysis, which arranges the findings first according to certain 'types' of horizontal effect that can be identified, and second, according to the ways in which the bodies have dealt with different kinds of non-State actor. This Part 5 also includes a brief critical comment on the Committee's reasoning in the practice analysed. Final conclusions are drawn in Part 6. 2017 www.ohchr.org/EN/HRBodies/Pages/TBGeneralComments.aspx; and UN OHCHR, 'Jurisprudence'. Retrieved 18 October 2017 http://juris.ohchr.org/. 


\subsection{Vertical vs. Horizontal Effect}

It is common knowledge among international lawyers that the nature of international human rights obligations is vertical - being owed by the State (as obligation-holder) to the individual (as beneficiary). ${ }^{36}$ The term 'vertical' demonstrates that the State, as the primary subject of and regulated by international law, is placed on a 'higher' playing field than the individual, who typically operates within a State and is therefore regulated by national law. The vertical effect of human rights law stems predominantly from the fact that, as the original subjects of international law, only States can become party to human rights treaties and therefore be legally bound by their obligations (although Jan Hessbruegge emphasises that this incapacity does not exclude obligational relationships in the non-State sphere ${ }^{37}$ ). Furthermore, only States can be the subject of individual complaints or cases before international human rights treaty monitoring bodies and regional human rights courts. Despite the increased power and influence of non-State actors, there have been no real correlative developments in (binding) international human rights law allowing for obligations to be applied between two (or more) non-State actors. The application of international human rights law between non-State actors is known as the 'horizontal effect' of human rights and will form the basis of the legal analysis undertaken in this article.

The terms 'direct horizontal effect' and 'indirect horizontal effect' are very often used in the fields of constitutional law and private law, particularly within the European context. ${ }^{38}$ Much of the debate surrounding horizontal

${ }_{3} 6$ At the national level, it could be possible for non-State actors to be human rights obligation-holders, if allowed for in domestic legislation or case law.

37 He argues that the fact that non-State actors cannot be the subject of an individual complaint for a human rights violation does not mean that non-State actors do not have any human rights obligations. Rather, he notes that '[i]nternational law routinely recognizes the existence of rights and obligations without offering a judicial forum in which to enforce them.' See Hessbruegge, 'Human Rights Violations Arising from conduct of NonState Actors' (n 9) 31-33; see also A. Clapham, Human Rights in the Private Sphere (Oxford: Clarendon Press, 1993).

38 In the context of fundamental rights within the European Union, see, e.g., S. Walkila, Horizontal Effect of Fundamental Rights in EU Law (Groningen: Europa Law Publishing, 2016); M. Safjan, 'The Horizontal Effect of Fundamental Rights in Private Law - On Actors, Vectors and Factors of Influence', in: K. Purnhagen and P. Rott (eds) Varieties of European Economic Law and Regulation (London: Springer International Publishing, 2014) 123; A. Colombi Ciacchi, 'Social Rights, Human Dignity and European Contract Law' 
effect comes from, in particular, Germany and the United Kingdom. ${ }^{39}$ However, the terms are also used at the international level, with scholars such as John $\mathrm{H}$ Knox discussing the 'horizontality' of international human rights law, and Thomas Gammeltoft-Hansen considering the 'direct' and 'indirect' responsibilities and obligations of non-State actors. ${ }^{40}$ Although rarely, the term 'direct horizontal effect' has also been used by one of the UN human rights treaty monitoring bodies (see Section 4.1.1).

\subsection{Direct Horizontal Effect}

The direct horizontal effect of human rights treaties would 'la[y] duties directly upon a private body to abide by its provisions and mak[e] breach of these duties directly actionable at the instance of an aggrieved party' ${ }^{\prime 1}$ In other words, it would place non-State actors under direct and explicit obligations to respect, protect and/or fulfil human rights (see Section 3.3.1).

Direct horizontal effect is sometimes discussed from the perspective of a victim of a human rights violation, in which case it is considered to have two components - substantive and procedural. Substantive horizontal effect would enable individuals to claim violations of rights owed to them by

in: S. Grundmann (ed) Constitutional Values and European Contract Law (Alphen aan den Rijn: Kluwer Law International, 2008) 149; A. Colombi Ciacchi, 'Horizontal Effect of Fundamental Rights, Privacy and Social Justice', in: K.S. Ziegler (ed) Human Rights and Private Law: Privacy as Autonomy (Oxford: Hart Publishing, 2007) 53. See further, H. Collins, 'On the (In)compatibility of Human Right Discourse and Private Law', in: H.-W. Micklitz (ed) Constitutionalization of European Private Law (Oxford: Oxford University Press, 2014) 26; G. Brüggemeier, A. Colombi Ciacchi and G. Comandé (eds) Fundamental Rights and Private Law in the European Union, Vol. I and II, Comparative Analyses of Selected Case Patterns (Cambridge University Press: Cambridge, 2010) 281.

39 See e.g. J.F. Krahé, 'The Impact of Public Norms on Private Law Relationships: Horizontal Effect in German, English, ECHR and EU Law', European Journal of Comparative Law and Governance2 (2015) 124-155; A.L. Young, 'Horizontality and the Human Rights Act 1998', in: K.S. Ziegler (ed) Human Rights and Private Law: Privacy as Autonomy (Oxford: Hart Publishing, 2007) 35; G. Phillipson, 'The Human Rights Act, 'Horizontal Effect' and the Common Law: A Bang or a Whimper?', The Modern Law Review 62(6) (1999) 824. For discussion of horizontal effect in the German context, see for example, K. Preedy, 'Fundamental Rights and Private Acts - Horizontal Direct or Indirect Effect? - A commentary', European Review of Private Law 1 (2000) 125.

T. Gammeltoft-Hansen, 'The Practice of Shared Responsibility of Private Actor Involvement in Migration Management', in: A. Nollkaemper and I. Plakokefalos (eds) The Practice of Shared Responsibility in International Law (Cambridge: Cambridge University Press, 2016). 
non-State actors, whilst procedural horizontal effect would allow an individual to 'enforce his fundamental rights against another individual'. 42 At the international level, this would challenge the existing rule that complaints of human rights violations may only be brought before human rights monitoring bodies (and for the most part, human rights courts) by individuals against States. ${ }^{43}$ In today's international human rights framework, this is not possible. As it stands, neither substantive nor procedural direct horizontal effect can be found in international human rights law. This has been reiterated many times, for example by the Human Rights Committee in General Comment 31: 'obligations are binding on States and do not, as such, have direct horizontal effect as a matter of international law' (see Section 4.1.1). ${ }^{44}$

Although this is the current state of play, there have been significant strides towards direct horizontal effect for business enterprises. Most notably, in July 2014 the UN Human Rights Council adopted Resolution 26/9, through which it established an open-ended, intergovernmental working group with the mandate 'to elaborate an internationally legally binding instrument to regulate, in international human rights law, the activities of transnational corporations and other business enterprises. 45 The working group has made considerable progress, with its latest report showing that a detailed framework and overview of the contents of a treaty on business and human rights has been developed. ${ }^{46}$

42 P. Van Dijk, and G.J.H. Van Hoof, Theory and Practice of the European Convention on Human Rights ( ${ }^{\text {rd }}$ edn, The Hague: Kluwer Law International, 1998) 23 [emphasis added].

43 See, for example, Article 1 Optional Protocol ICCPR. Un General Assembly, 'Optional Protocol to the International Covenant on Civil and Political Rights', 19 December 1966, United Nations Treaty Series vol. 999, 171. Some human rights bodies allow complaints to be brought by other actors, such as non-governmental organisations, on behalf of an individual. However, the object of the complaint is always the individual concerned.

44 UN Human Rights Committee (HRCtee), 'General comment No. 31: The nature of the general legal obligation imposed on States Parties to the Covenant', 26 May 2004, CCPR/C/21/ Rev.1/Add.13, para. 8.

45 UN Human Rights Council, Resolution 26/9, 'Elaboration of an international legally binding instrument on transnational corporations and other business enterprises with respect to human rights', 14 July 2014, A/HRC/RES/26/9. See also Lane, 'Private providers of essential public services and de jure responsibility for human rights', in: M. Hesselman, A. Hallo de Wolf and B. Toebes (eds) Socio-economic human rights in essential public service provision (London: Routledge, 2017) 139 at 152-153.

46 Chairmanship of the open-ended intergovernmental working group, 'Elements for the Draft Legally Binding Instrument on Transnational Corporations and Other Business Enterprises with Respect to Human Rights'. Retrieved 16 October 2017 http://www.ohchr .org/Documents/HRBodies/HRCouncil/WGTransCorp/Session3/LegallyBindingInstru mentTNCs_OBEs.pdf. 
However, it is it likely to be quite some time before a final version of the treaty has been adopted and gained enough State ratifications to enter into force.

Slightly earlier developments towards direct human rights obligations for businesses occurred through the adoption of the UN Guiding Principles on Business and Human Rights (UNGPs). ${ }^{47}$ The UNG Ps were drafted by John Ruggie in his capacity as Special Representative of the Secretary-General on the issue of human rights and transnational corporations and other business enterprises, and were unanimously endorsed by the UN Human Rights Council in 2011. ${ }^{48}$ Significantly, the UNGPs contain a direct responsibility (as opposed to an obligation) for businesses to respect human rights, as well as a responsibility to conduct human rights due diligence. ${ }^{49}$ Although the UNG PS are not legally binding, they have had a tremendous impact; both States and businesses have taken concrete action towards the implementation of the UNG Ps. This includes, for example, the adoption of 'National Action Plans'50 and national legislation by States (see below) and measures such as human rights impact assessments, human rights policy statements, reporting and training by businesses. ${ }^{51}$

The Organisation for Economic Cooperation and Development Guidelines for Multinational Enterprises (OECD Guidelines) ${ }^{52}$ have also helped to pave the way to direct horizontal effect for businesses. The OECD Guidelines were first adopted in 1976 and have been reviewed several times. The most recent review took place in 2011 and resulted in the addition of a new chapter on human rights which is consistent with the UNGPS, strengthening the commitment

47 UN Human Rights Council, UNGPs (n 16).

48 UN Human Rights Council, Resolution 17/4, 16 June 2011, A/HRC/REs/17/4.

49 Un Human Rights Council, UNG Ps (n 16), Principles 11 and 17.

50 National Action Plans detail the government's activities and plans on how to help businesses improve their respect of human rights. For more information, see UN OHCHR, 'State national action plans'. Retrieved 17 October 2017 www.ohchr.org/EN/Issues/ Business/Pages/NationalActionPlans.aspx.

$5^{1}$ For an extensive database detailing the action that has been taken by businesses and States to implement the UNGPs, see the Business and Human Rights Resource Centre, 'Type of Steps Taken'. Retrieved 17 October 2017 www.business-humanrights.org/en/un -guiding-principles/implementation-tools-examples/implementation-by-companies/ type-of-step-taken.

52 Organisation for Economic Cooperation and Development (OECD), 'OECD Guidelines for Multinational Enterprises’' 27 June 2000 (revised version 2011). Retrieved 16 October 2017 www.oecd.org/corporate/mne/ (oECD Guidelines). 
to human rights already included in the OECD Guidelines. ${ }^{53}$ As with the UNGPS, the OECD Guidelines are not legally binding. However, they require adhering States to establish a 'National Contact Point' (NCP), making it the only instrument on the responsibility of businesses that has a built-in grievance mechanism. ${ }^{54}$ NCPs are mandated to 'provide a mediation and conciliation platform for helping to resolve cases' of non-compliance with the OECD Guidelines. ${ }^{55}$ Since the 2011 revision, the number of NCP cases dealing with human rights has increased dramatically. ${ }^{56}$ However, even before this, some NCPS referred to international human rights treaties in their 'Final Statement' on a case.${ }^{57}$ While important, this is not altogether surprising, since the previous version of the Guidelines (adopted in 2000) provided that companies should 'respect the human rights of those affected by their activities consistent with the host government's international obligations and commitments', 58 and explicitly referred to the human rights legal framework.

53 Although the OECD Guidelines do include specific recommendations on human rights, they focus on responsible business conduct more generally. For an explanation of the Guidelines' content, aims and implementation, see OECD, 'OECD Guidelines for Multinational Enterprises: Responsible Business Conduct Matters' (2014) 2. Retrieved 17 October 2017 http://mneguidelines.oecd.org/MNEguidelines_RBCmatters.pdf.

Ibid.

55 OECD, 'Cases handled by the National Contact Points for the oECD Guidelines for Multinational Enterprises' 1. Retrieved 17 October 2017 http://mneguidelines.oecd.org/Flyer -OECD-National-Contact-Points.pdf.

56 Ibid.

57 See, for example, uK National Contact Point for the oEcD Guidelines for Multinational Enterprises, 'Final Statement of 25 September 2009 (Survival International vs Vedanta Resources plc.)', No. 58-62. The case concerned a British mining company called Vedanta Resources operating in India, which was found to have failed to conduct adequate impact assessments regarding in indigenous and human rights. Ultimately, the NCP found that the company 'did not respect rights and freedoms ... consistent with India's commitments under various international human rights instruments.' See Amnesty International UK, 'Briefing for U K National Contact Point on Human Rights Implementation of oECD Guidelines for Multinational Enterprises' (February 2013) 9-10. Retrieved 17 October 2017 www.oecdwatch.org/publications-en/Publication_3966. See also oECD Watch, 'Survival International vs Vedanta Resources plc'. Retrieved 17 October 2017 www.oecdwatch.org/ cases/Case_165; and I. Kanalan, 'Horizontal Effect of Human Rights in the Era of Transnational Constellations: On the Accountability of Private Actors for Human Rights Violations', in: M. Bungenberg et al. (eds) European Yearbook of International Economic Law 2016 (Cham: Springer International Publishing, 2016) 423.

58 OECD, 'OECD Guidelines for Multinational Enterprises', 27 June 2000, General Policies Chapter, para. 2. Retrieved 17 October 2017 www.oecd.org/corporate/mne/200ooecdg uidelinesformultinationalenterprises.htm. See for discussion, Amnesty International 
Perhaps the UNGPs' and OECD Guidelines' most significant contribution to (binding) direct horizontal effect has been their influence on legislation adopted at the national and European level. Notable examples can be found in the United Kingdom. For example, both The Companies Act 2006 (Strategic Report and Directors' Report) Regulations 2013 and the Modern Slavery Act 2015 contain provisions requiring certain businesses to disclose information related to human rights. ${ }^{59}$ In the Modern Slavery Act in particular, this extends, for businesses over a certain size, to information as to 'what action they have taken to ensure there is no modern slavery in their business or supply chains'. ${ }^{60}$ Further examples of legislation influenced by the UNGPs can be found in France and the Us. ${ }^{61} \mathrm{~A}$ recent law passed in France requires certain companies to make 'vigilance plans' that must, inter alia, include 'reasonable vigilance measures to

UK, 'Briefing for U K National Contact Point on Human Rights Implementation of OECD Guidelines for Multinational Enterprises' (n 57 ) 4.

59 Section $414 \mathrm{C}(7)(\mathrm{b})$ The Companies Act 2006 (Strategic Report and Directors' Report) Regulations 2013 No. 1970 requires quoted companies to prepare a 'strategic report' which must contain a review of the company's business 'to the extent necessary for an understanding of the development, performance or position of the company's business, include ... social, community and human rights issues, including information about any policies of the company in relation to those matters and the effectiveness of those policies.' Examples of regional legislation influenced by the UNGPs include: European Union, Directive 2014/95/EU amending Directive 2013/34/EU as regards disclosure of non-financial and diversity information by certain large undertakings and groups (22 October 2014); and European Union, Regulation 2017/821/EU laying down supply chain due diligence obligations for Union importers of tin, tantalum and tungsten, their ores, and gold originating from conflict-affected and high-risk areas (17 May 2017). See also CLt Envirolaw, 'Overview of key Business \& Human Rights Legislation for companies'. Retrieved 16 October 2017 www .business-humanrights.org/sites/default/files/media/documents/clt_human_rights _legislation-1.pdf.

6o UK Government website, 'Modern Slavery Act 2015'. Retrieved 16 October 2017 www.gov .uk/government/collections/modern-slavery-bill; Part 6, Section 54(4) Modern Slavery Act 2015 .

61 An example from the us includes the California Transparency in Supply Chains Act (Civil Code Section 1714.43; Senate Bill 657 (Steinberg) (2009-10)). The legislation requires that certain private companies disclose 'efforts to eradicate slavery and human trafficking from [their] direct supply chain for tangible goods offered for sale'. For discussion, see K.D. Harris. 2015. 'The California Transparency in Supply Chains Act: A Resource Guide'. Retrieved 17 October 2017 https://oag.ca.gov/sites/all/files/agweb/pdfs/sb657/resource -guide.pdf. 
identify risks and prevent serious violations of human rights and fundamental freedoms.' ${ }^{62}$

Further developments towards direct horizontal effect have been made through the jurisprudence of several national legal systems. A full discussion falls outside the scope of this article due to its international focus, but it is interesting to see that some courts have held private owners of publicly accessible spaces to be directly bound by the fundamental rights to freedom of expression and freedom of assembly. ${ }^{63}$ In effect, the private owners' enjoyment of their property rights have been limited in order to allow individual/s to exercise their right to freedom of expression/assembly. ${ }^{64}$ Other courts, though not going this far, have engaged in discussions concerning how much discretion private property owners have for what concerns the enjoyment of freedom of expression/assembly on their property and whether public property owners

62 Loi no. 2017-399 du 27 mars 2017 relative au devoir de vigilance des sociétés mères et des entreprises donneuses d'ordre (Jo du 28 ${ }^{\text {eme }}$ mars 2017, no.1) (Law No. 2017-399 on the Duty of Care of Parent Companies and Ordering Companies). See for discussion S. SmithVidal and C. Dauthier, Morgan Lewis \& Bockius LLP, 2017. 'French Companies Must Show Duty of Care for Human and Environmental Rights'. Lexology, 3 April. Retrieved 17 October 2017 www.lexology.com/library/detail.aspx?g=bbife739-c51a-4313-84bf-b7a444ef 4701.

63 The cases have been decided at the provincial and state level as well as the national level. See e.g. Supreme Court of California, Robbins v. Pruneyard Shopping Center [1979] 23 Cal. 3rd 899. A similar example is a decision of the Federal Constitutional Court of Germany in which a private and publicly owned airport was held to be directly bound by fundamental rights. However, the airport in question was $52 \%$ State-owned, giving the State a 'controlling influence', which enabled the Court to avoid discussing the property rights of the airport owners and reduces the significance of the outcome for what concerns direct horizontal effect. See BVerfG, 1 BvR 699/o6 vom 22.2.2011, Absatz-Nr. (1-128). Retrieved 20 October 2017 www.bundesverfassungsgericht.de/SharedDocs/Entscheidungen/EN/2011/02/rs20110222_1bvro699o6en.html; O. Salát, 'From the Mass Mind to Content Neutrality: Freedom of Assembly in a Comparative Perspective' (2012). Retrieved 20 October 2017 www.etd.ceu.hu/2012/salat_orsolya.pdf.

64 In the case of Robbins v. Pruneyard Shopping Center (n 63) for example, the privatelyowned shopping centre that had refused to allow a group of high school students to solicit signatures for a petition to the government were obliged to allow the solicitation on the basis that 'Sections 2 and 3 of article I of the California Constitution protect speech and petitioning, reasonably exercised, in shopping centers even when the centers are privately owned.' A similar finding had been made by the United States Supreme Court in the case of Marsh v. Alabama 326 U.S.501 [1946], although such outcomes appear to be relatively rare. See for discussion Salát, 'From the Mass Mind to Content Neutrality' (n 63) 370 . 
enjoy the same level of discretion. ${ }^{65}$ Similar case law can also be found at the regional level, although in these proceedings the State has remained the ultimate obligation-holder rather than the relevant private actor, thereby ruling out direct horizontal effect. ${ }^{66}$

At the international level, although not within the realm of international human rights law, there have also been cases in which human rights obligations have been upheld against private actors. For example, in a significant case in 2014 the European Court of Justice balanced the rights and interests of an internet search engine operator (Google) against those of a 'data subject' (an individual). ${ }^{67}$ In applying the relevant law (the Data Protection Directive ${ }^{68}$ ) it considered the Charter of Fundamental Rights of the European Union. ${ }^{69}$ It found that unless interference with the data subject's rights to privacy and data protection could be justified, they would 'as a rule' take preference over the rights and interests of the internet search engine operator and the general public. ${ }^{70}$

Similar cases have also been decided by private dispute arbitrations or example, the World Intellectual Property Organization has upheld the right to freedom of expression against a private corporation and has interpreted the policy to be applied in the case by reference to international human rights

65 Supreme Court of Canada, Committee for the Commonwealth of Canada v. Canada [1991] 1 SCR 139; Ontario Provincial Court Criminal Division, $R$ v. Jack Layton [1986] CarswellOnt 792, 38 c.c.c. (3 d) 550; Supreme Court of the United States, International Society for Krishna Consciousness v. Lee [1992] 505 Us 672.

66 An example of this is the case of Appleby v. United Kingdom at the European Court of $\mathrm{Hu}-$ man Rights, in which a balance of the claimants' right to freedom of expression against the private owner's right to property was conducted. The Court held that had the actions of the private owner sufficiently barred the effective exercise of the claimants' freedom of expression, the UK would have been required to take action to protect the individuals' right (i.e. to require the private owner to respect freedom of expression at the expense of their own right to property). Appleby and Others $v$. UK, App No 44306/98 (2003) para. 47.

67 ECJ Case C-131/12 Google Spain, SL, Google Inc v. Agencia Espanola de Proteccion de Datos 13 May 2014 available at http://eur-lex.europa.eu/legal-content/EN/ TXT/?uri=CELEX\%3А62012CJo131.

68 Directive 95/46/EC of the European Parliament and of the Council of 24 October 1995 on the protection of individuals with regard to the processing of personal data and on the free movement of such data, OJ $1995 \mathrm{~L} 281 / 31$.

69 OJ C 326, 26.10.2012, 391-407.

70 Google Spain, SL, Google Inc v. Agencia Espanola de Proteccion de Datos (n 67) para. 97. An interference could be justified by the 'preponderant interest of the general public in having, on account of inclusion in the list of results, access to the information in question.' 
law. ${ }^{71}$ The International Centre for the Settlement of Investment Disputes which hears investment disputes between States (acting as private actors) and private actors has also considered human rights law in some decisions. ${ }^{72}$ However, this remains an exception rather than the rule, and scholars have pushed for further consideration of human rights in investment arbitration, ${ }^{73}$ warning against 'considering international investment law in a vacuum. ${ }^{74}$ For example, arguing for greater harmonisation between international human rights and international investment law, Bruno Simma and Theodor Kill suggest using international human rights law as 'external rules' when interpreting investment treaties. ${ }^{75}$

Finally, in recent years there have been several instances of international bodies holding non-State actors (in particular non-State armed groups) to be bound by some jus cogens norms. For example, in 2012 the Commission of Inquiry on the Syrian Arab Republic (the body established by the UN Human Rights Council to investigate alleged violations of international human rights

71 WIPO Arbitration and Mediation Center, Bridgestone Firestone, Inc., Bridgestone/Firestone Research, Inc., and Bridgestone Corporation v. Jack Myers, Case No D2000-019o, discussed in Kanalan, 'Horizontal Effect of Human Rights in the Era of Transnational Constellations' (n 57) 453-454.

72 As Kanalan notes, this has even been true in cases where the parties, who determine the applicable law in a given dispute, have not agreed that human rights law will be applicable. Kanalan, 'Horizontal Effect of Human Rights in the Era of Transnational Constellations' (n 57) 454-455.

73 For a very detailed discussion of the relationship between international human rights and investment law, the ways in which human rights are brought into investment disputes and suggestions as to how human rights could be better integrated into investment arbitration, see P.-M. Dupuy et al. (eds) Human Rights in International Investment Law and Arbitration (Oxford: Oxford University Press, 2010); A. Kulick, Global Public Interest in International Investment Law (Cambridge: Cambridge University Press, 2012).

74 B. Simma and T. Kill, 'Harmonizing Investment Protection and International Human Rights: First Seps Towards a Methodology', in: C. Binder et al. (eds) International investment law for the 21st century. Essays in honour of Christoph Schreuer (Oxford: Oxford University Press, 2009) 678 at 679 .

75 See ibid. The use of external rules is consistent with the rules of interpretation found in the Vienna Convention on the Law of Treaties (23 May 1969, entered into force 27 January 1980) United Nations Treaty Series, vol. 1155, 331. A similar argument has been made by Pierre-Marie Dupuy, in P.-M. Dupuy, 'Unification Rather than Fragmentation of International Law? The Case of International Investment Law and Human Rights Law', in: P.-M. Dupuy et al. (eds) Human Rights in International Investment Law and Arbitration (Oxford: Oxford University Press, 2010) 45. 
law since March 2011 ${ }^{76}$ ) in the country stated that 'at a minimum, human rights obligations constituting peremptory international law (jus cogens) bind States, individuals and non-State collective entities, including armed groups. ${ }^{77}$ This has been reiterated by the UN Mission in the Republic of South Sudan, which found the same obligations to bind non-State armed opposition groups as well as States. ${ }^{78}$ These claims are strengthened by international criminal law, which enables members of non-State armed groups to be held individually responsible at the international level for violations of some jus cogens obligations. ${ }^{79}$ However, in this context the obligations are not framed as part of human rights, but criminal law, and therefore cannot be considered true examples of direct horizontal effect of international human rights law.

Further developments towards direct horizontal effect are buttressed by scholars via the suggestion of new theories or bases for direct horizontal effect. ${ }^{80}$ Specifically, some literature suggests focusing on our understanding of human rights themselves, as opposed to human rights law, in order to justify placing direct human rights obligations on non-State actors. ${ }^{81}$ Ibrahim Kanalan is one proponent of this approach, arguing that many previous theories of direct horizontal effect fall short because of their focus on staying within the

76 UN Human Rights Council, Resolution S-17/1, A/HRC/RES/s-17/1.

77 Report of the Independent International Commission of Inquiry on the Syrian Arab Republic, A/HRC/19/69, para. 106, cited in Geneva Academy. 2016. 'Human Rights Obligations of Armed Non-State Actors: An Exploration of the Practice of the Un human Rights Council'. Academy In-Brief No. 7, 22. Retrieved 24 October 2017 www.geneva-academy.ch/ joomlatools-files/docman-files/InBrief7_web.pdf.

78 'Report of the Special Rapporteur on freedom of religion or belief, Heiner Bielefeldt', A/HCR/28/66, 29 December 2014, paras. 54 and 56, cited in Geneva Academy, 'Human Rights Obligations of Armed Non-State Actors' (n 77) 29.

79 Article 25 Rome Statute of the International Criminal Court (adopted 17 July 1998, entered into force 1 July 2002) allows individuals to be held 'individually responsible and liable for punishment' at the international level for committing war crimes, crimes against humanity, genocide or crimes of aggression. Although not all of these can also be said to be human rights standards, according to M. Cherif Bassiouni, they all have the status of jus cogens. M.C. Bassiouni, 'International Crimes: Jus Cogens and Obligatio Erga Omnes', Law and Contemporary Problems 59(4) (1996) 63 at 68.

8 o See e.g. N. Carillo-Santarelli, Direct International Human Rights Obligations of non-State Actors: A Legal and Ethical Necessity (Oisterwijk: Wolf Legal Publishers, 2017).

81 See e.g. M. Nowak and K.M. Januzewski, 'Non-State Actors and Human Rights', in: M. Noortmann, A. Reinisch and C. Ryngaert (eds) Non-State Actors in International Law (Oxford: Hart Publishing, 2015) 113 at 118; and Kanalan, 'Horizontal Effect of Human Rights in the Era of Transnational Constellations' ( $\mathrm{n}$ 57). 
confines of the international legal framework. ${ }^{82}$ He suggests a new concept based on the 'normative power of human rights and the consideration of the functional differentiation of society'. ${ }^{83}$ Other scholars have taken a broader perspective, developing theories of shared responsibility between State and non-State actors, ${ }^{84}$ as well as 'multi-duty bearer regimes'. ${ }^{85}$ A discussion of the projects falls outside the scope of this article, but they are extremely interesting and show that scholars are working to fill the 'accountability gap' arising from the lack of direct horizontal effect in new ways. ${ }^{86}$

All of these examples show that at the national, regional and international levels, real developments have been made in various contexts towards the direct horizontal effect of human rights. Nonetheless, most of the concrete, binding developments have taken place outside of international human rights law, the direct application of which between non-State actors remains extremely limited.

82 Kanalan, 'Horizontal Effect of Human Rights in the Era of Transnational Constellations' (n 57$)$.

83 Ibid 456. Within his work Kanalan relies on 'systems theory' and in part on the work of Gunther Teubner, who has also addressed new theories of direct horizontal effect. See e.g. Teubner, 'The anonymous matrix' (n 11); and G. Teubner, 'Transnational Fundamental Rights: Horizontal effect?', Rechtsfilosofie \& Rechtstheorie 40 (2011) 191.

84 The 'shares' Research Project on Shared Responsibility in International Law has been steadily growing in its reach and output, and offers 'new concepts, principles and perspectives for understanding how the international legal order may deal with shared responsibility' between State and non-State actors. It specifically focuses on allocating responsibility to multiple actors that have contributed to the same violation of international law, and has dealt with the issue of the lack of direct, binding human rights obligations for non-State actors. See e.g. SHAREs website. Retrieved 24 October 2017 www .sharesproject.nl/; D'Aspremont et al. 'Sharing Responsibility Between Non-State Actors and States in International Law' (n 15).

85 See e.g. W. Vandenhole and W. van Genugten, 'Introduction: An emerging multi-dutybearer human rights regime?', in: W. Vandenhole (ed) Challenging Territoriality in Human Rights Law: Building blocks for a plural and diverse duty-bearer regime (Abingdon: Routledge, 2015) 1.

86 Wouter Vandenhole and Willem van Genugten, for example, suggest a 'fundamental rethinking of [the] basic tenet of human rights law', that 'human rights obligations are primarily incumbent on the territorial State'. ibid. See also L. Lane and M. Hesselman, 'Governing Disasters: Embracing Human Rights in a Multi-Level, Multi-Duty Bearer, Disaster Governance Landscape', Politics and Governance 5(2) (2017) 93 at 101. 


\subsection{Indirect Horizontal Effect}

Due to the lack of direct horizontal effect of international human rights, a concept of 'indirect horizontal effect' has emerged. In a situation of indirect horizontal effect, it is the State, not the responsible non-State actor, against whom the victim brings a claim of an interference with their human rights. As such, the State is also the entity that is (if the claim succeeds) legally recognised as being responsible for the harm suffered by the victim. This is regardless of the fact that the act interfering with the human right was done by a non-State actor. Essentially, this results in a diagonal application of human rights, through a State's direct obligation to protect individuals from the harmful actions of other non-State actors (see below). Under this construct, while the State remains directly responsible, indirect obligations, which derive from international law, are imposed on non-State actors; it may well be that through the State's fulfilment of its obligation to protect, a non-State actor is under an obligation to adhere to certain human rights standards imposed by national law (thereby receiving direct obligations at the national level as well). ${ }^{87}$ However, this article is concerned with horizontal effect at the international level. Because of the construction of indirect horizontal effect based on the obligation to protect (see Section 3.3.1), this article's analysis could be seen as an examination of the obligation to protect, as well as indirect horizontal effect as such (from the perspective of non-State actors).

The analysis also deals to some extent with State responsibility, in particular the International Law Commission's 'Draft Articles on Responsibility of States for Internationally Wrongful Acts' (DASR). ${ }^{88}$ The DASR, although never becoming a binding treaty, are now widely considered to constitute customary international law and have been widely applied in practice. ${ }^{89}$ Published together with commentary on each article, the DASR specify under what circumstances a State can be held responsible for a violation of international law (that there is an act or omission that '(a) is attributable to the State under international

87 Indeed, this activity is expected of States under international human rights law - as Manfred Nowak and Karolina Januzewski state, 'international law confines itself to regulate non-state actor behavior through indirect horizontal obligations requiring the state to intervene, through domestic legislation and other appropriate measures'. See M. Nowak and K.M. Januzewski, 'Non-State Actors and Human Rights', in: M. Noortmann, A. Reinisch and C. Ryngaert (eds) Non-State Actors in International Law (Hart Publishing, 2015) 113 at 141.

88 International Law Commission, 'Draft Articles on Responsibility of States for Internationally Wrongful Acts with Commentaries' Vol. II Part Two Yearbook of the International Law Commission (2001) 30-143 (DASR).

89 See United Nations, Materials on the Responsibility of States for Internationally Wrongful Acts, ST/LEG/SER в/25 (New York: United Nations, 2012). 
law; and (b) constitutes a breach of an international obligation of the State'). ${ }^{90}$ Chapter II DASR specifically details how/when conduct can be attributed to the State. The commentary to Chapter II DASR explains that although as a general rule, only the actions of State agents can be attributed to the State, it may also be 'responsible for the effects of the conduct of private parties, if it failed to take necessary measures to prevent those effects. ${ }^{91}$ In particular, the following conduct may be attributed to the State: (i) the conduct of 'persons or entities exercising elements of governmental authority' (e.g. privatised corporations that retain public or regulatory functions);92 (ii) conduct 'directed or controlled by a State'; 93 (iii) conduct 'carried out in the absence or default of the official authorities'; 94 (iv) conduct of insurrectional or other movements; 95 and (v) conduct 'acknowledged and adopted by a State as its own'. ${ }^{96}$ While the analysis in Section 4 does not focus on the DASR, it is certainly interesting to bear them in mind; some parallels can be drawn between the DASR and the reasoning of the human rights treaty monitoring bodies, which sometimes refer to the 'attribution' of non-State actor conduct to the State in their application of indirect horizontal effect. However, as will be shown below, the bodies rarely mention the DASR explicitly.

Because the focus here is on the international level, the definition of indirect horizontal effect adopted above differs somewhat from popular definitions in the national or European context - Gavin Phillipson, for instance, defines indirect horizontal effect as meaning that 'whilst the rights cannot be applied directly to the law governing private relations and are not actionable per se in such a context, they may be relied upon indirectly, to influence the interpretation and application of pre-existing law'. ${ }^{97}$ This definition is more relevant at the domestic level, where it is possible to have cases in which both parties are non-State actors, and will not be applied in this article. Under Phillipson's understanding, it would fall to the national judiciary to apply international human rights standards when giving judgments, even when they are dealing with a case that only involves non-State actors. ${ }^{98}$

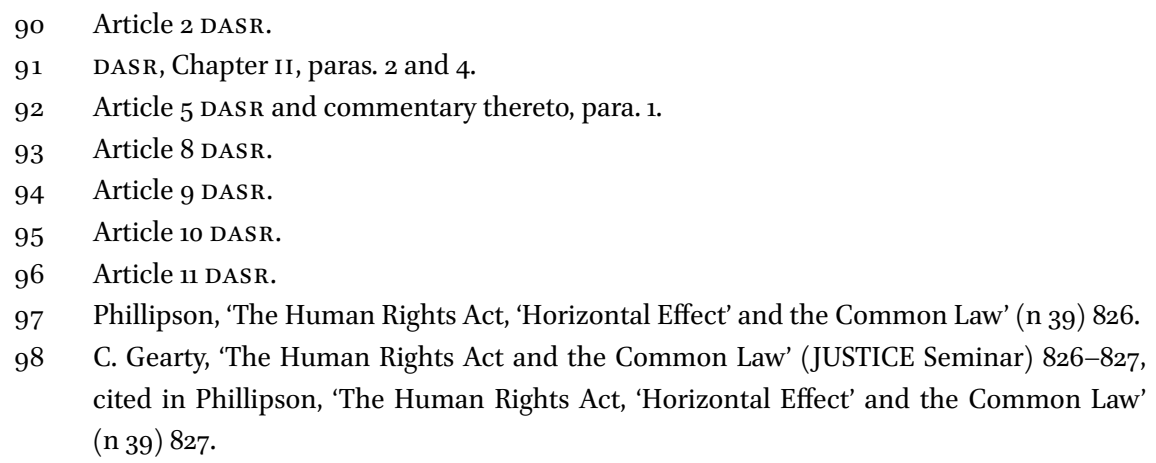


Despite some academics believing that the distinctions between direct and indirect horizontal effect are simply a matter of semantics, ${ }^{99}$ there is quite a large practical difference between them, ${ }^{100}$ particularly for the victim of a violation. There is a crucial ideological distinction between seeing the actual perpetrators of the violations as 'real' subjects of international law as opposed to holding only the State responsible. At some point, we have to let go of the habit of seeing exclusively the State as some kind of 'parental' figure, wholly and singularly responsible for guaranteeing the welfare of its citizens, ${ }^{101}$ and allow the non-State actors - often more akin to adolescents (torn somewhere between the dependent individual, and the autonomous, independent nation-State) to take on responsibility for their own actions. The perpetual obstacle here is determining at which point this line should be drawn, and how. Should there be a method akin to the 'Gillick competence' test developed in UK common law to determine this by applying established criteria?102 How can standards be differentiated according to different types of non-State actor? Is it legitimate to establish international norms to force non-State actors to operate in a certain way? A discussion of all of the possibilities falls outside of the scope of this article, but these questions should be borne in mind when reading the analysis.

Indirect horizontal effect has been denounced by some as not being a particularly useful modus operandi. Thomas Bennett has declared it to be 'an inexact method for the supposed protection of what are meant to be the basic, fundamental rights of individuals'. ${ }^{103}$ This point deserves due credit. On the one hand, the consequences of successful indirect horizontal effect cases can be to further human rights protection and to require the State to adopt more effective measures to protect individuals from harm by non-State actors, thereby going further than a simple case-by-case impact, resulting in broader improvements for human rights protection. On the other hand, the potential impacts of indirect horizontal effect are constrained by the restrictions of the powers

99 J.H. Knox, 'Horizontal Human Rights Law' 102(1) The American Journal of International Law (2008) 128.

$100 \quad$ Ibid.

101 C. Jochnick, 'Confronting the Impunity of Non-State Actors: New Fields for the Promotion of Human Rights', Human Rights Quarterly (1999) 56 at 59.

102 This test is used to determine whether or not a child has the competence to consent to or deny medical treatment without the consent of her legal guardian. See UK House of Lords, Gillickv. West Norfolk and Wisbech Area Health Authority [1985] 3 ALL ER 402.

103 T.D.C. Bennett, 'Horizontality's New Horizons - re-examining horizontal effect, privacy, defamation and the Human Rights Act: Part 1', Entertainment Law Review 21(3) (2010) 96 at 96 . 
of courts and supervisory bodies to interpret international human rights law in a legitimate way (i.e. according to the confines of the Vienna Convention on the Law of Treaties ${ }^{104}$ ). The courts, in abiding by these limits, are often unable to provide victims of human rights interference with effective remedies (or even hear cases concerning non-State actors) which would otherwise be available had the perpetration been done by a different actor.

\subsubsection{The State Obligation to Protect Human Rights}

The obligation to protect very commonly forms the basis of indirect horizontal effect and was alluded to above. It will not be discussed in detail here, but rather introduced, to provide context for the practice of the monitoring bodies below that relies on States' positive obligations.

The obligation to protect human rights forms one part of tripartite typology of State obligations. The typology consists of the obligations to respect, protect and fulfil human rights, and was proposed in its current form by Asbjørn Eide. ${ }^{105}$ According to Eide, the protective function of human rights is the most important of all. ${ }^{106}$ Indeed, the obligation to protect has been afforded a huge amount of attention by legal scholars and practitioners alike.

In concrete terms, the obligation to protect ideally results in the prevention of interference by non-State actors through the incorporation and/or implementation of human rights treaty standards in a State's domestic laws and policies. This has been interpreted to require States to take immediate steps to ensure that violations by the State, its agents, and non-State actors are prevented. ${ }^{107}$ It should also include providing access to impartial legal remedies in the case of any violations, regardless of the identity of the perpetrator. ${ }^{108}$ As an example,

104 See Articles 31 and 32. United Nations, Vienna Convention on the Law of Treaties, 23 May 1969, United Nations Treaty Series vol. 1155, 331. For an in-depth discussion of the rules of interpretation under the Convention, see M. Fitzmaurice, O. Elias and P. Merkouris (eds) Treaty Interpretation and the Vienna Convention on the Law of Treaties: 30 Years On (Leiden: Martinus Nijhoff Publishers, 2010).

105 A. Eide, 'Report on the Right to Adequate Food as a Human Right', E/CN.4/Sub.2/1987/23 (1987). An earlier typology proposed by Henry Shue included obligations to 'avoid, protect and aid' human rights. See H. Shue, Basic Rights, Subsistence, Affluence and U.S Foreign Policy, (Princeton: Princeton University Press, 1980) 160.

106 A. Eide, 'Economic, Social and Cultural Rights as Human Rights', in: A. Eide, C. Krause, and A. Rosas (eds) Economic, Social and Cultural Rights: A Textbook, (Martinus Nijhoff Publishers, 2005) 9 at 30.

107 UN OHCHR. 2005. 'Economic, Social and Cultural Rights: Handbook for National Human Rights Institutions'. Professional Training Series No. 12, 17-18.

108 Ibid. 
Principle 6 of the Maastricht Principles on Extraterritorial Obligations of States in the Area of Economic, Social and Cultural Rights ${ }^{109}$ explained the obligation as meaning that the failure of States to ensure that private employers comply with basic labour standards may amount to a violation of the right to work or the right to just and favourable conditions of work (protected under Article 7 of the International Covenant on Economic, Social and Cultural Rights). ${ }^{110}$ In the context of economic, social and cultural rights, the UN Handbook for National Human Rights Institutions states that the obligation to protect requires States to take 'active measures to protect all persons from racial or other forms of discrimination, harassment and the withdrawal of services'.111

A major aspect of the State obligation to protect human rights is the duty of due diligence, which exists in several areas of international law. Due diligence is an obligation of conduct rather than result, meaning that it is more the tangible effort, and 'progressive' steps made by States which fulfil the obligation, rather than the success of these actions per se. ${ }^{112}$ In the human rights context it 'requires action reasonably calculated to realize the enjoyment of a particular right',113 whereas an obligation of result would require 'States to achieve specific targets to satisfy a detailed substantive standard.'114 At first sight, this may appear to be a less demanding or even effective type of obligation, but in reality it is necessary in situations where the State may not have automatic control over private actors, making the actual realisation of rights unrealistic (perhaps a notion connected to the 'minimum core obligation' which recognises the differing capacities of States to fulfil rights immediately, and allowing their progressive realisation). ${ }^{115}$

109 FIAN International. 2013. 'Maastricht Principles on Extraterritorial Obligations of States in the Area of Economic, Social and Cultural Rights'. Retrieved 24 October 2017 www.etoconsortium.org/nc/en/main-navigation/library/maastricht-principles/?tx _drblob_pi1 $\% 5$ BdownloadUid $\% 5 \mathrm{D}=23$.

110 Ibid, Principle 6. The Maastricht Principles are not legally binding, however they 'aim to clarify the content' of States' obligations relating to economic, social and cultural rights in an extraterritorial context. That the obligation is delineated as such in this specific context, in which any State obligations are under contestation, supports an argument that they be so delineated within a State's territory and jurisdiction as well. See ibid, preamble.

111 UN OHCHR, 'Economic, Social and Cultural Rights' (n 107) 18.

112 Ibid 61.

113 International Commission of Jurists. 1997. 'Maastricht Guidelines on Violations of Economic, Social and Cultural Rights'. 26 January, para. 7. Retrieved 24 October 2017 www1 .umn.edu/humanrts/instree/Maastrichtguidelines_.html.

114 Ibid.

115 This concept was elaborated upon by the Committee on Economic, Social and Cultural Rights in its explanation of Article 2(1) ICESCR which stipulates this to be the nature of the rights within it. See ibid. 
Joanna Bourke-Martignoni's evaluation of due diligence in the context of violence against women appears to suggest that the duty would also extend to addressing the causes of human rights violations by non-State actors, ${ }^{116}$ as well as introducing domestic laws to ensure the effective investigation and redress when they have occurred. This supports the idea that one of the main tenets of the obligation to protect is the prevention of interferences by nonState actors; as the saying goes, prevention is better than cure. In the context of the prohibition on the use of child soldiers, Radhika Coomaraswamy also formulated, in her previous capacity as Special Rapporteur on Violence against Women, a 'checklist' of measures which would fulfil the duty of due diligence, including 'appropriate measures in the field of education and the media to raise awareness', ${ }^{117}$ thus entailing quite extensive steps to be fulfilled.

As a principle in international law more generally, due diligence may depend on the foreseeability of a non-State actor's conduct. As Robert Barnidge explains, it could involve particular knowledge of the State (i.e. of some intended harm, which they could have prevented but failed to do so). ${ }^{118}$ The duty must also be exercised in relation to the transboundary effects of acts by private individuals within a State's jurisdiction, as was held in the Trail Smelter case. ${ }^{119}$ The practical extent of the duty differs according to prevailing circumstances, and according to the resources available to a State. This is because the duty is context-dependent, meaning that the scope of actions required by the State is dependent on the situation on the ground. For example, in the context of diplomatic law, the usual degree of (host-State) police presence required outside an embassy would be low (if required at all), requiring little State action. However, in the event of a protest or riot aimed at the embassy and taking place in its vicinity, more police action would be required to control the

116 J. Bourke-Martignoni, “The History and Development of Due Diligence Standard in International Law and Its Role in the Protection of Women Against Violence', in: C. BenningerBudel (ed) Due Diligence and its Application to Protect Women from Violence (Leiden: Martinus Nijhoff Publishers, 2008) 47 at 56.

117 R. Coomaraswamy, 'Report of the Special Rapporteur on violence against women', Un Doc E/CN.4/1999/68 (10 March 1999), para. 25, cited in Bourke-Martignoni, 'The History and Development of Due Diligence Standard in International Law and Its Role in the Protection of Women Against Violence' (n 116) 56.

118 R. Barnidge, 'The Due Diligence Principle under International Law', International Community Law Review 8(1) (2006) 81 at 94.

119 Reports of International Arbitral Awards, Trail Smelter Case, (United States, Canada), 16 April 1938 and 11 March 1941, Vol. III, 1905-1982, in Barnidge, 'The Due Diligence Principle under International Law' (n 118) 99-102. 
situation and prevent unlawful behaviour. ${ }^{120}$ Similar standards can be said to have developed in the human rights context, which will be seen through the analysis in Section 4.

Due diligence has been applied as a principle under international human rights law by many monitoring bodies, examples of which will be discussed below. While it has been interpreted and applied slightly differently by the various bodies, a very common expression of the duty is that to 'prevent, investigate and punish' human rights violations by private actors. ${ }^{121}$

It is important to be aware that the changes taking place in relation to globalisation, privatisation and the increased power of non-State actors may affect the way in which due diligence develops. On the one hand, the changing nature of the relationship between certain non-State actors, the State and individuals, and the taking on of more traditionally State functions by non-State actors (i.e. through the provision of state services), may mean that the scope of the obligation to protect and the duty of due diligence will expand accordingly. As a State delegates or outsources more activities to non-State actors, it may be necessary for a wider-ranging duty to emerge. This may already be happening in relation to some actors. The UNGPs, for example, detail the duties that States should observe in relation to businesses. The Principles provide for concrete measures that States should take to protect individuals from the harmful actions of businesses. For example, they require States to ensure that there are effective mechanisms in place for individuals to gain redress for human rights-related harm they have suffered at the hands of businesses. ${ }^{122} \mathrm{We}$ see similar standards in the OECD Guidelines for Multinational Enterprises, ${ }^{123}$ through the aforementioned requirement that adhering States establish National Contact Points to deal with situations in which a multinational corporation is believed to have negatively affected an individual's human right. ${ }^{124}$ More recently, a general comment on business and human rights was adopted by the Un Committee on Economic, Social and Cultural Rights, explaining in

120 This was seen to some extent in the United States Diplomatic and Consular Staff in Tehran (Hostages) case (United States of America v. Iran), ICJ Reports 1980, 3, in which the ICJ held Iran to have failed in its duty of due diligence to protect the premises of the us embassy in Tehran, and to act preventively, (despite giving previous assurances) when the embassy was sieged by private actors. See Barnidge, 'The Due Diligence Principle under International Law' (n 118) 110-113.

121 See e.g. Inter-American Court of Human Rights, Velásquez-Rodríguezv. Honduras, IACtHR (Ser.C) No.4 (29 July 1988) paras. 79 and 172.

122 UN Human Rights Council, UNG Ps (n 16) Principle 25.

123 OECD, 'OECD Guidelines for Multinational Enterprises (revised version 2011)' (n $5^{2}$ ).

124 Ibid Guideline 11. 
quite some detail the due diligence obligations (among others) of States vis-àvis business enterprises (See Section 4.2.1).

On the other hand, the new levels of influence being reached by some nonState actors could mean that the obligation to protect becomes increasingly difficult to fulfil. For example, again in the context of multinational corporations, it may be difficult to obtain information relating to their daily operations in order to prevent human rights interference. Non-governmental organisations trying to improve the human rights impact of corporations in the coal industry have often found that corporations are unwilling to share information with States, or with the public at large. ${ }^{125}$ Short of States obliging corporations to provide information, it may be difficult to determine which measures need to be taken by States under the duty of due diligence in order to ensure that the daily operations of such corporations do not infringe the human rights of (for example) their employees. A worrying trend of political influence of corporations may even mean that the State is unable to take the requisite measures to oblige a corporation to publicise information without the threat of losing the investment of the corporation within their territory. ${ }^{126}$

In addition, the vast range of non-State actors and the circumstances in which they operate may make it impractical to develop concrete standards that States should follow under the duty of due diligence. Indeed, this may not even be desirable given that the contextual nature of the duty suggests a caseby-case analysis of what States must do. The fact that due diligence is a duty of conduct rather than result is also relevant again here. Although reasonable (it has to be acknowledged that States do not have an unlimited capacity to act, particularly due to resource restraints), this underlines the major setback of the obligation to protect in achieving its aim of protecting individuals from the harmful actions of non-State actors. A victim who brings a complaint against a State on the basis of the obligation to protect will not be able to gain any kind of redress for the violation of their rights if the State has taken all feasible measures and still failed to regulate the actions of the non-State actor to the effect

\footnotetext{
125 See somo and ICN. 2013. 'Time for Transparency: The case of the Tamil Nadu textile and garment industry'. sомо and ICN Paper, 1-2. Retrieved 24 October 2017 www.indianet.nl/ pdf/TimeForTransparency.pdf.

126 D. Aguirre, 'Multinational Corporations and the Realisation of Economic, Social and Cultural Rights', California Western International Law Journal 35 (2004) 53 at 53-54. Worryingly, this extends to influence at the global level, for example over policy-making at the World Trade Organization. See Action Aid Trade Justice Campaign. 20o6. 'Under the influence: Exposing undue corporate influence over policy-making at the World Trade Organization'. Retrieved 24 October 2017 www.actionaid.org.uk/sites/default/files/doc _lib/174_6_under_the_influence_final.pdf.
} 
that they respect human rights. The lack of direct horizontal effect precludes the victim from getting a remedy vis-à-vis the direct perpetrator of the harmful acts, and the duty of due diligence precludes them from achieving indirect horizontal effect, whereas if the case had been brought against the State which had, itself, committed the same actions as the non-State actor in this scenario, the victim would have been able to gain some kind of redress. Further critique of indirect horizontal effect will be left to the following sections' analysis of horizontal effect in practice.

4

\section{Horizontal Effect of International Human Rights in International Practice}

\subsection{Human Rights Committee}

The Human Rights Committee (HRCtee) is the designated treaty monitoring body for the International Covenant on Civil and Political Rights (ICCPR).127 The next sections will analyse first the Committee's general comments, and then its views on individual complaints, to see whether and how it has dealt with situations in which non-State actors have interfered with the enjoyment of human rights (i.e. whether and how it engages with the horizontal effect of human rights).

\subsubsection{General Comments of the Human Rights Committee}

The HRCtee 'takes its authority ... from article 40, paragraph 4, of the Covenant, which provides that it may transmit "such general comments as it may consider appropriate" to all States parties'.128 The general comments of the HRCtee apply to all State Parties to the ICCPR. The HRCtee has referred to various types of horizontal effect in its general comments, the most pertinent examples of which will now be discussed. It should be mentioned at the outset that the HRCtee's interpretations of the ICCPR have often been heavily criticised for its forthcoming and at times overreaching nature, ${ }^{129}$ which 'preclude[s] any

127 International Covenant on Civil and Political Rights (16 December 1966, entered into force 23 March 1976) United Nations Treaty Series vol. 999, 171.

128 UN онсhr, 'Civil and Political Rights: The Human Rights Committee' (n 22 ) 24.

129 See, for example, the observations of the US and the UK to General Comment No. 24. 'Observations by the Governments of the United States and the United Kingdom on $\mathrm{Hu}-$ man Rights Committee General Comment No. 24 (52) relating to reservations'. Retrieved 24 October 2017 www.iilj.org/wp-content/uploads/2016/o8/US-and-UK-Responses-to-the -General-Comment.pdf. 
claim that the assertions made [...] represent an international consensus of any kind.' ${ }^{130}$ Although the Committee may at times appear to overstep the mark, its interpretations related to non-State actors and horizontal effect do not go beyond the scope of interpretation allowed by Article 31 of the Vienna Convention on the Law of Treaties. ${ }^{131}$

The most explicit discussion of horizontal effect in relation to the ICCPR by the HRCtee can be found in General Comment No. $31 .{ }^{132}$ The general comment focuses on the definition and scope of obligations found within the ICCPR. In the context of obligations for non-State actors, the Committee acknowledged that 'as a matter of international law', the obligations within the ICCPR 'do not, as such, have direct horizontal effect'.133 However, it did go on to elaborate how indirect horizontal effect can be applied to obligations contained in the Covenant. Commenting upon Article 2(1) ICCPR (declaring the nature of State obligations), the HRCtee held that States do indeed have positive obligations which require them to protect individuals 'against acts committed by private persons or entities that would impair the enjoyment of Covenant rights'.134 Specifically, the Committee determined the positive obligations to mean that 'State Parties' permitting or failing to take appropriate measures or to exercise due diligence to prevent, punish, investigate or redress the harm caused by such acts by private persons or entities' could result in a violation of a Covenant right. ${ }^{135}$ This clearly reflects States' obligations to protect human rights from interference by third parties, in particular the standard of due diligence introduced above.

130 Us Department of State. 2008. 'Observations of the United States of America on the Human Rights Committee's General Comment 33: The Obligations of States Parties under the Optional Protocol to the International Covenant on Civil and Political Rights'. 22 December, para. 2. Retrieved 24 October 2017 www.state.gov/documents/organization/138852. pdf. This statement was made in the context of assertions of the Committee as to their legal authority, but the principal notion (that disagreement by State Parties affects the influence of the general comments) may be applied to other general comments by the Committee.

131 In particular, the HRCtee seems to rely on Article 31(3)(b), which allows 'any subsequent practice in the application of the treaty which establishes the agreement of the parties regarding its interpretation' to be considered when interpreting a treaty, along with the context of the provision (stipulated in paragraph 2 of Article 31).

132 Un HRCtee, 'General Comment No. 31' (n 44).

133 Ibid para. 8.

134 Ibid.

135 Ibid. 
However, the statements in General Comment No. 31 were not positively received by some States. The Unites States of America (Us), for example, published observations on the comment condemning the Committee's assertions as 'sweep[ing] too broadly and categorically'. ${ }^{136}$ Rejecting the idea put forward by the Committee that all human rights within the Covenant contain positive obligations (drawn from the Committee's use of Article 2(1) as the basis for positive obligations), the us believed that each right must be considered separately in order to determine whether, and to what extent, the State could be expected to take positive action to ensure its protected enjoyment. ${ }^{137}$ This more restrictive view of the us does not correspond very well with the views of other human rights bodies as to the positive obligations and the extent of the duty of due diligence under international human rights law (see below). The argument appears to value distinguishing rights from one another on the basis of rights, rather than obligations. This seems to clash with the tripartite typology of human rights (which by now has been widely accepted as applying equally to all human rights). ${ }^{138}$ The reluctance could stem from a (now outdated) belief that only economic, social and cultural rights require positive action by States, while civil and political rights should be equated with negative obligations only (i.e. an obligation to refrain from interfering with the enjoyment of rights). The us objected, in particular, to the consequence of the general comment that States would have a positive obligation to protect individuals from torture by private actors (this does not preclude, however, that they would be willing to accept a positive obligation to protect individuals from torture by public actors). ${ }^{139}$ The us found it paradoxical that such an effect could be read into the prohibition of torture provided in Article 7 ICCPR, without the Convention against Torture (which was subsequently specifically adopted for

136 Us Department of State. 2007. 'Observations by the United States of America on Human Rights Committee General Comment 31: Nature of the General Legal Obligation Imposed on States Parties to the Covenant'. 27 December, para. 11. Retrieved 18 October 2017 http://2001-2009.state.gov/s/l/2007/112674.htm.

137 Ibid paras. 11 and 13 .

138 See M. Sepúlveda, The Nature of the Obligations under the International Covenant on Economic, Social and Cultural Rights (Antwerp: Intersentia, 2003) (also for a discussion of the advantages of distinguishing between obligations, rather than rights); F. Coomans, 'The Ogoni Case Before the African Commission on Human and Peoples' Rights', International and Comparative Law Quarterly $5^{2}$ (2003) 749 at 752-753; International Commission of Jurists, 'Maastricht Guidelines on Violations of Economic, Social and Cultural Rights' (n 113).

139 See us Department of State, 'Observations by the United States of America on Human Rights Committee General Comment 31' (n 136) paras. 15-17. 
combatting torture) explicitly including a positive obligation. The argument here referred to the requirement in Article 1 of the Convention against Torture (САT) that torturous acts be done 'by, at the instigation of or with the consent or acquiescence of a public official, with no mention of non-State actors. ${ }^{140}$ As will be explained in detail below, the Committee against Torture has itself interpreted Article 1 CAT in the same way as the HRCtee, allowing for some degree of indirect horizontal effect.

Although at first sight the statement in General Comment No. $3^{1}$ seems to be quite far-reaching, the HRCtee may have curtailed its effect. The Committee restricted the extent of due diligence by stating that States' positive obligations only apply to rights 'so far as they are amenable to application between private persons or entities.' ${ }^{141}$ The lack of explanation of what is meant by this, however, dims the potential of this caveat to mollify States like the us. Because the HRCtee's general comments are not legally binding, for the time being States may be able to evade (binding) legal responsibility ${ }^{142}$ for positive obligations under the ICCPR, especially for those rights in relation to which the text of the Covenant does not expressly place such an obligation on States (unless and until such time as this interpretation becomes a matter of customary international law). ${ }^{143}$

General Comment No. 31 does give an important overview of the HRCtee's interpretation of human rights obligations within the ICCPR as a whole. However, the Committee has also published general comments pertaining to specific rights, which also involve horizontal effect and actually pre-date General Comment No. 31. It may be possible, therefore, for the earlier comments of the Committee to clarify the meaning of its more general observations on Article 2. The following discussion will shed light on which rights the Committee seems to view as being 'amenable to application between private persons or entities'.

\footnotetext{
140 Emphasis added. See ibid para. 17. The European Court of Human Rights has also interpreted the prohibition of torture in this way.

141 Un HRCtee, 'General Comment No. 31' (n 44) para. 8.

142 The us did openly acknowledge a moral and political responsibility of States to protect individuals from 'private acts of extreme physical abuse by private individuals', for example. See us Department of State, 'Observations by the United States of America on Human Rights Committee General Comment 31' (n 136) para. 18.

143 The obligations may be even less persuasive against the us as they have not ratified the Optional Protocol to the ICCPR, which would allow individuals to bring complaints against them before the Human Rights Committee.
} 
The rights-specific General Comments referring to horizontal effect of ICCPR rights include Comments $7,16,18,20,27$, and 28. ${ }^{144}$ The comments in these documents range from direction as to what standards States are expected to meet in relation to the relevant rights in the Covenant, to how States should fulfil their obligation to protect individuals, or calls for States to improve and provide evidence of the measures they take to protect individuals.

For example, General Comment No. 7 explicitly mentioned the State obligation to protect individuals from torturous acts, stating that 'the scope of protection required goes far beyond torture as normally understood', and, significantly, that 'it is also the duty of public authorities to ensure protection by the law against such treatment even when committed by persons acting outside or without any official authority.' ${ }^{145}$ This strong proclamation was superseded by more tempered wording by General Comment No. 20 which replaced No. 7. Nevertheless, General Comment No. 20 still requests that in their periodic reports to the Committee, State Parties provide information on the 'criminal law which penalize[s] torture and cruel, inhuman and degrading treatment or punishment' by any actor, including by private persons. ${ }^{146}$ It further requires that complaints of torture 'must be investigated promptly and impartially by competent authorities. ${ }^{147}$ While there is no specific mention of this relating to complaints against private persons, it can be assumed from the previous quotation that this would be expected, since the Committee sees the State as being responsible for protecting individuals from torture by private actors.

Regarding the right to privacy, the HRCtee stated in General Comment No. 16 that the 'right is required to be guaranteed against all such interferences and attacks whether they emanate from State authorities or from natural or

144 See respectively, General Comment No. 20 (replacing General Comment No. 7): UN HRCtee, 'General Comment No. 20: Article 7 (Prohibition of Torture, or Other Cruel, Inhuman or Degrading Treatment or Punishment)', 10 March 1992; Un HRCtee, 'General Comment No. 16: Article 17 (Right to Privacy), The Right to Respect of Privacy, Family, Home and Correspondence, and Protection of Honour and Reputation', 8 April 1988; UN HRCtee, 'General Comment No. 18: Non-discrimination', 10 November 1989, CCPR/C/21/ Rev.1/Add.9; un HRCtee, 'General Comment No. 27: Article 12 (Freedom of Movement)', 2 November 1999; Un HRCtee, 'General Comment No. 28: Article 3 (The Equality of Rights Between Men and Women)', 29 March 2000, CCPR/C/21/Rev.1/Add.10.

145 Emphasis added. un HRCtee, 'General Comment No. 7: Article 7 (Prohibition of Torture or Cruel, Inhuman or Degrading Treatment or Punishment)', 30 May 1982, para. 2.

146 UN HRCtee, 'General Comment No. 2o' (n 144) para. 13.

147 Ibid para. 14. 
legal persons ${ }^{\prime 148}$ - an implicit reference to the obligation to protect. The Committee went on to explain what kind of measures this required. In particular, it mentioned that States must regulate by law the 'gathering and holding of personal information on computers, data banks and other devices' by public and private actors, ensure that individuals can 'ascertain which public authorities or private individuals or bodies control or may control their files' and 'have the right to request rectification or elimination' of files collected or processed unlawfully or that contain incorrect personal data. ${ }^{149}$ Here, the HRCtee has gone quite far, compared to its comments regarding other rights, in detailing how the right to privacy should be safeguarded against interference by private actors.

The HRCtee also mentions specific measures to be taken vis-à-vis non-State actors in General Comment No. 18 on the subject of non-discrimination. The HRCtee required States to provide evidence of their legal provisions and administrative measures directed at diminishing or eliminating' discrimination carried out by private actors. ${ }^{150}$ General Comment No. 28 on the equality of rights between men and women requests States to 'report on any laws and public or private actions that interfere with the equal enjoyment by women of the rights under article 17 , and on the measures taken to eliminate such interference and to afford women protection from any such interference'. ${ }^{\prime 151}$ These comments clearly impose the obligation to protect upon States, requiring due diligence to be taken by implementing laws to prevent and punish interference with the enjoyment of (particularly women's) rights by private actors.

It is very interesting that the majority of the instances in which the Committee has spoken of or implicitly applied indirect horizontal effect of rights within the ICCPR have been in relation to groups that are generally considered to be 'vulnerable'. In particular, the Committee has upheld the obligation to protect with regards to women and individuals deprived of their liberty or freedom of movement. Another example is General Comment No. 27 on freedom of movement, which demonstrates the importance that the HRCtee places on the obligation to protect to women as a vulnerable group. In this comment, the Committee opined that individuals must be 'protected not only from public

\footnotetext{
148 UN HRCtee, 'General Comment No. 16' (n 144) para. 10. See also Clapham, Human Rights Obligations of Non-State Actors (n 18) 331.

149 Ibid.

$15^{0}$ Un HRCtee, 'General Comment No. 18' (n 144).

151 Emphasis added. Un HRCtee, 'General Comment No. 28' (n 144) para. 20.
} 
but also from private interference', the 'obligation to protect [being] particularly pertinent' in relation to women. ${ }^{152}$

It could be argued that General Comment No. 31 attempts to take this obligation out of the realm of the enjoyment of specific rights by particular groups by upholding indirect horizontal effect more generally. To identify the Committee's approach to horizontal effect in a more holistic manner, the jurisprudence resulting from its individual complaints procedure under Article 1 of the Optional Protocol to the ICCPR will also be briefly assessed, in so far as it adds value to the findings of the General Comments.

\subsubsection{Views of the Human Rights Committee}

Pursuant to Article 1 of the Optional Protocol to the ICCPR, the HRCtee can hear individual communications 'from individuals subject to [a State Party's] jurisdiction who claim to be victims of a violation by that State Party'. ${ }^{153}$ The Optional Protocol entered into force in 1976, and has resulted in almost 3,000 communications being brought before the Committee. ${ }^{154}$ Of those cases in which a 'view' was adopted, it is possible to see evidence of indirect horizontal effect.

For example, the case of B.d.B. v. The Netherlands concerned nondiscrimination under Article 26 ICCPR. ${ }^{155}$ The communication was actually declared inadmissible by the Human Rights Committee, but remains interesting due to the Committee's comments regarding the author of the alleged human rights violation. The claimants alleged that a non-State actor, the Industrial Insurance Board for Health and for Mental and Social Interests, had discriminated against them in relation to social security contributions. ${ }^{156}$ The Netherlands wished to rely on the fact that the Board is a non-State actor as one of its arguments against admissibility of the complaint. The main argument was that because the Board is an independent body (established merely

152 UN HRCtee, 'General Comment No. 27: Article 12 (Freedom of Movement)', 2 November 1999, CCPR/C/21/Rev.1/Add.9, para. 6.

153 Optional Protocol to the International Covenant on Civil and Political Rights. To date, there are 115 State Parties to the Optional Protocol. See the UN Treaty Database. Retrieved 24 October 2017 https://treaties.un.org/Pages/ViewDetails.aspx?src=IND\&mtdsg_no=IV $-5 \&$ chapter $=4 \&$ lang $=$ en.

154 A statistical survey of the jurisprudence of the Human Rights Committee is available via the website of the UN OHCHR. Retrieved 24 October 2017 www.ohchr.org/EN/HRBodies/ CCPR/Pages/CCPRIndex.aspx.

155 Un HRCtee, B.d.B. et al. v. The Netherlands (1989) Communication No. 273/1989, un Doc. Supp. No. $40(\mathrm{~A} / 44 / 40)$ at 286.

$15^{6} \quad$ Ibid para. 2.1. 
to 'implement social security legislation'), ${ }^{157}$ the Dutch State could not 'influence concrete decisions' of the Board. ${ }^{158}$ Because of this, the Netherlands argued that it could not be held responsible for discrimination on behalf of the Board. The HRCtee, however, had a different point of view. It observed that the Dutch State was 'not relieved of its obligations under the Covenant when some of its functions are delegated to other autonomous organs.' 159 Through this statement, the Committee seems to imply that the Netherlands remains responsible here because the conduct of the non-State actor could be attributed to the State. Although the State was not directly controlling the Board, it had delegated traditionally 'public' functions to it, and thus would have retained responsibility for any discrimination that would have arisen from the Board's decisions (had the case been assessed on its merits).

The reasoning in B.d.B. v. The Netherlands was later reiterated and to some extent also clarified by the Committee in Cabal and Pasini v. Australia. ${ }^{160}$ The latter communication was brought in relation to alleged discrimination by a privatised prison. The HRCtee again held that 'contracting out to the private commercial sector of core State activities which involve the use of force and the detention of persons' does not diminish the responsibility of the State; it remains an obligation of the State to ensure that the rights of individuals are protected vis-à-vis these private actors, the conduct of whom could be attributed to the State.

The HRCtee has discussed the obligation to protect in other cases that take place in a 'quasi-public sphere'. In discussing the admissibility of the case of Nahlikv. Austria, for example, the HRCtee explicitly referred to the State's obligation to protect individuals from discrimination 'among private parties'. ${ }^{161}$ This seems to reiterate General Comment No. 31, but its significance for horizontal effect is weakened due to the 'quasi-public' context. The case concerned alleged discrimination that had occurred through a private agreement. The Austrian State tried to rely on this fact to have the communication declared inadmissible. However, the HRCtee reaffirmed that States must protect individuals from discrimination 'within the public sphere or among private parties in

\footnotetext{
157 Ibid para. 4.7.

158 Ibid.

159 Ibid para. 6.5.

160 Un HRCtee, Mr. Carlos Cabal and Mr. Marco Pasini Bertran v. Australia (2003) Communication No. 1020/2001, UN Doc. CCPR/C/78/D/1020/2001.

161 UN HRCtee, Franz Nahlik v. Austria (1996) Communication No. 608/1995, UN Doc. CCPR/C/57/D/608/1995.
} 
the quasi-public sector of, for example, employment'.162 Additionally, because agreement had to be confirmed by a public body before it could enter into force, the State was deemed to be in a position to protect the individual from discrimination through the agreement. Ultimately, the case was declared inadmissible on other grounds. Nevertheless, the statement made about private parties does demonstrate that the HRCtee believes non-discrimination to be one of the rights 'amenable to application' between private actors.

In contrast, the right to participation in the public life of the nation (protected by Article 25 ICCPR) does not seem to be considered as amenable in the same way. In the case of Karakurt $v$. Austria the HRCtee emphasised that Article 25 could 'not extend to cover private employment matters'. ${ }^{163}$ Interestingly, in another case involving Article 25 (Arenz v. Germany), the Committee did suggest that the right to freedom of religion was subject to the 'obligation to ensure' all rights in the ICCPR, including Article 25, and in relation to private associations as well as State actors. ${ }^{164}$ The complaint centred on the fact that a religiously-founded political party had denied the claimants membership of the party due to their membership of a different ideological organisation. The claimants argued that through upholding this decision, the German national courts had interfered with their right to take part in public affairs. The Committee rejected this argument, however, on the grounds that it was not the function of the Committee (not being an appeals court) to re-evaluate the German national courts' application of German domestic law, as long as there was no arbitrariness or denial of justice. ${ }^{165}$ Despite not going to the merits, this case does show, to a limited degree, that a right so inherently linked to the public sphere can also be amenable to relationships between private actors. Because the applicants did not focus on this in their communication, however, the HRCtee restrained itself from 'address[ing] the broader issue of what legislative and administrative measures' must be taken to ensure the enjoyment of Article $25 \cdot{ }^{166}$

\footnotetext{
162 Ibid para. 8.2.

163 UN HRCtee, Karakurt v. Austria (2002) Communication No. 965/2000, UN Doc. CCPR/C/ 74/D/965/2000, para. 8.2.

164 Emphasis added. The use of the word 'ensure' rather than 'protect' is interesting here. Whether the same meaning was intended by the HRCtee is unclear, as no explanation of what the obligation entails was provided. Un HRCtee, Arenz v. Germany (2004) Communication No. 1138/2002, UN Doc. CCPR/C/80/D/1138/2002, para. 8.5.

165 Ibid para. 8.6.

166 Ibid.
} 

Committee

It may be concluded from the above examples that the HRCtee does indeed engage with the idea that non-State actors could cause infringements of human rights. So far, the Committee has not been particularly radical in its application of the obligation to protect human rights. Despite the backlash surrounding General Comment No. 31, it appears to have been based on a line of previous general comments within which the Committee elaborated on States' positive obligations to protect human rights from both public and private actors. It cannot be said, however, that the Committee has been as extensive in its views on individual communications. It is likely that this is because of the restrictions of what the Committee could discuss imposed by the subject matter of the complaint itself (e.g. in Arenz v. Germany) or simply because the cases in which issues of horizontal effect have arisen have tended to be declared inadmissible, thus not warranting a detailed examination or application of the relevant provisions vis-à-vis non-State actors.

What is clear is that when the HRCtee engages with the obligation to protect, it requires certain measures to be taken by States to ensure that human rights protection is engrained on an institutional level within States (i.e. within their legal or administrative frameworks). As with other human rights monitoring bodies, when faced with human rights interference by a privatised actor or with a situation where the State has delegated certain 'public' tasks, the HRCtee has not hesitated to attribute the actions to the State. It also has not shied away from applying States' obligation to protect in relation to rights that are often affected within private relationships, such as privacy and nondiscrimination, although the HRCtee seems to tread more carefully with rights that are of a more public nature (e.g. Article 25 ICCPR). In terms of concrete indirect obligations for non-State actors at the international level (through direct obligations imposed by domestic law), the HRC has remained quite general. The actual standards that States are expected to hold non-State actors to prevent them from interfering with human rights are very vague. Most aspects of the obligation to protect that are discussed by the Committee go either to procedural obligations (i.e. due diligence), or simply state that, for example, non-State actors should not be permitted to discriminate. The HRCtee therefore predominantly stays within the realm of State's direct obligations rather than non-State actors' indirect ones.

Ultimately, whatever approach the HRCtee takes in its interpretation and application of the ICCPR, it remains limited by the international human rights framework, its non-binding nature and, regarding the individual communications procedures, the very cases that appear before it. 


\subsection{Committee on Economic, Social and Cultural Rights}

The Committee on Economic, Social and Cultural Rights (CteeESCR) has made quite widespread implicit references to indirect horizontal effect in relation to the International Covenant on Economic, Social and Cultural Rights (ICESCR). ${ }^{167}$ As with the HRCtee, the CteeESCR's general comments will be addressed before moving on to its jurisprudence. ${ }^{168}$ The CteeESCR is not technically a 'UN treaty body' in the same sense as the other bodies discussed here, but will be treated as an equivalent body. ${ }^{169}$

\subsubsection{General Comments of the Committee on Economic, Social and Cultural Rights}

The CteeESCR has consistently applied the tripartite typology of human rights, and focuses most of its consideration of indirect horizontal effect on the State obligation to protect. ${ }^{170}$

Even before the CteeESCR engaged with the full typology explicitly, it was applying some degree of indirect horizontal effect by applying States' protective obligations regarding human rights. For example, in General Comment No. 5 on persons with disabilities, the CteeESCR emphasised that the private sphere must be appropriately regulated by the State to ensure the protection of people with disabilities from inequitable treatment. ${ }^{171}$ This could (and indeed has by some scholars) be seen as an 'obligation to regulate' private actors. ${ }^{172}$ Going into more detail, CteeESCR explicitly mentioned that it is essential that private employers, private suppliers of goods and services, and other

167 International Covenant on Economic, Social and Cultural Rights (16 December 1966, entered into force 3 January 1976) United Nations Treaty Series vol. 999, 3.

168 Although the use of this term may be controversial as the supervisory bodies cannot deliver binding judgments, this is the wording used by the Office of the High Commissioner for Human Rights.

169 The CteeESCR was established not by the relevant core human rights treaty (in this case the ICESCR) as the other monitoring bodies were, but rather at a later point by the United Nations Economic and Social Council (Ecosoc). See Ecosoc, Resolution 1985/17, 'Review of the composition, organization and administrative arrangements of the Sessional Working Group of Governmental Experts on the Implementation of the International Covenant on Economic, Social and Cultural Rights', E/RES/1985/17 (1985).

170 For a discussion of the UN CteeESCR's use of the typology, see I.E. Koch, 'Dichotomies, Trichotomies, or Waves of Duties?', Human Rights Law Review $5(1)$ (2005) 81.

171 UN CteeESCR, 'General Comment No. 5: Persons with Disabilities', 9 December 1994, E/1995/22, para. 11.

172 See Hallo de Wolf, Reconciling Privatization and Human Rights (n 18) 142-145; see also M. Hesselman and L. Lane, 'Disasters and non-state actors - Human rights-based approaches', Disaster Prevention and Management 26(5) (2017) $5^{26}$. 
non-public entities be subject to both non-discrimination and equality norms in relation to persons with disabilities' - an idea that was reaffirmed in General Comment No. 14 on the right to health. ${ }^{173}$ The statement in General Comment No. 5 cannot be read as implying that the CteeESCR is in favour of subjecting private actors directly to international human rights law. Rather, it requires States to adopt national norms concerning economic, social and cultural rights which must be applied within the private sphere (i.e. in private relationships). Indeed, the CteeESCR emphasised that the 'ultimate responsibility' for ensuring that people with disabilities' Covenant rights are complied with lies with the State. ${ }^{174}$ The CteeESCR appeared to be particularly concerned that this was the case in relation to privatised public services - a concern consistent with that expressed by the HRCtee above. Indeed, very similar language was used by the CteeESCR here as by the HRCtee in B.d.B. v. The Netherlands; the CteeESCR pointed out that delegation of activities by the State to private actors does not 'absolve' the State of its international obligations, whereas the HRCtee explained that the same did not 'relieve' a State of its obligations. ${ }^{175}$

In the context of the right to food, the CteeESCR made similar claims regarding States' obligation to protect and the fact that this necessitates State regulation of the private sphere, in General Comment No. $12 .{ }^{176}$ Here, the CteeESCR reiterated that '[v]iolations of the right to food can occur through the direct action of States or other entities insufficiently regulated by States', confirming that violations can occur when the harm is directly caused by nonState actors. ${ }^{177}$ A subsequent general comment on the right to water extended the requirement of a regulatory regime of private providers of public services to include a punitive aspect in case of non-compliance by the private actor. ${ }^{178}$

173 UN CteeESCR, 'General Comment No. 14: The Right to the Highest Attainable Standard of Health (Art. 12 of the Covenant)', 11 August 2000, E/C.12/200o/4, para. 26.

174 Ibid para. 12, 'ultimate responsibility' being a quotation by UN CteeESCR of the World Programme of Action concerning Disabled Persons, adopted by the General Assembly through resolution 37/52 of 3 December 1982 (para. 1), para. 165 .

175 See B.d.B. v. The Netherlands (n 155) para. 6.5. See also Un CteeESCR, 'General Comment No. 5 ' (n 171) para. 12.

176 UN CteeESCR, 'General Comment No. 12: The Right to Adequate Food (Art. 11 of the Covenant)', 12 May 1999. This was reiterated in other General Comments (see below), including General Comment No. 16. See un CteeESCR, 'General Comment No. 16: The Equal Right of Men and Women to the Enjoyment of All Economic, Social and Cultural Rights (Art. 3 of the Covenant)', 11 August 2005, E/C.12/2005/4, para. 20.

177 UN CteeESCR, 'General Comment No. 12' (n 176) para. 19.

178 See un CteeESCR, 'General Comment No. 15 The Right to Water (Arts. 11 and 12 of the Covenant)', 20 January 2003, E/C.12/2002/11, para. 24. 
Failing to adopt an effective regulatory system would, according to the Committee, result in a violation of the obligation to protect, and therefore of Covenant rights. ${ }^{179} \mathrm{~A}$ similar statement can be found again in General Comment No. 23 on the right to just and favourable conditions of work. In the context of States' obligation to protect human rights, the CteeESCR emphasised that States must 'tak[e] steps to prevent, investigate, punish and redress abuse through effective laws and policies and adjudication.' ${ }^{180}$ Taken together, these general comments not only create a framework for the obligation to regulate private actors, but also expound the Committee's view of what the duty of due diligence requires of States. Curiously, the CteeESCR did not mention an explicit duty of 'due diligence' until General Comment No. 16, and since then, it has not been consistent in using the term. This is not necessarily significant, as it can be argued that by providing States with guidance as to how they can fulfil the obligation to protect individuals, and what measures they should take for the prevention and punishment of non-State actors for certain conduct (such as the inclusion of the punitive aspect of regulatory regimes), the Committee is implicitly referring to due diligence, or at least leads to comparable obligations. This is particularly persuasive when the explicit language in different general comments is compared. Explicit reference was made in General Comment No. 16, in which the CteeESCR calls upon States to 'act with due diligence to prevent, investigate, mediate, punish and redress acts of violence against them by private actors.' 181 This is almost identical to the language of General Comment No. 23, quoted above. The reason for the inconsistency is unclear, although an explicit use of 'due diligence' returns repeatedly in the Committee's most recent general comment on business and human rights (see below). As with the HRCtee, the CteeESCR's treatment of non-State actors so far does not contain concrete or detailed standards against which they should be held, even at the national level. Rather, because of the focus on due diligence and regulation, there is again an emphasis on States' procedural obligations. It could be assumed that the substantive standards to which non-State actors should be held therefore match those of the State (at least in terms of defining particular terms, such as 'access' to certain services, or in determining whether,

179 UN CteeESCR, 'General Comment No. 14' (n 173) para. 51; UN CteeESCR, 'General Comment No. 15 ' (n 178 ) para. 44 (b).

180 UN CteeESCR, 'General comment No. 23 (2016) on the right to just and favourable conditions of work (article 7 of the International Covenant on Economic, Social and Cultural Rights)', 27 April 2016, E/C.12/GC/23, para. 59 .

181 UN CteeESCR, 'General Comment No. 16' (n 176) para. 27. 
for example, discrimination has occurred). On the other hand, it could also be assumed that the standards fall within States' margin of appreciation.

The CteeESCR has also discussed potential responsibilities of non-State actors themselves, for example in General Comment No. 12 on the right to adequate food. The CteeESCR emphasised (again) the fact that only States retain ultimate accountability for ensuring the right to food. ${ }^{182}$ Significantly, though, it also highlighted that all members of society have a role to play in the realisation of this right. ${ }^{183}$ This would seem to go further than the (generally accepted) assertion that non-State actors may have an international responsibility (although not a legal obligation) to respect human rights. The statement suggests that private actors may have a more 'positive' role vis-à-vis the right to food. While this is suggested by the wording of the comment, the CteeESCR has not made it explicit. In fact, in General Comment No. 12 the CteeESCR seemed to be more concerned with the actions of private businesses interfering with human rights and the State's obligation to prevent this, rather than any positive action that private businesses themselves could or should be making to contribute to the realisation of the right to food. Although not going into the positive actions of business vis-à-vis human rights realisation, the CteeESCR has gone so far as to explain how businesses should act so as to avoid interfering with the right to food (i.e. by operating 'within the framework of a code of conduct conducive to respect of the right to adequate food, agreed upon jointly with the Government and civil society'). ${ }^{184}$ This goes further than the comments discussed until this point, as it makes explicit reference to the possibility that non-State actors could have some responsibilities to take action, at least in terms of a responsibility to respect the right. The CteeESCR repeated the relevant passage almost verbatim in its General Comment No. 14 on the right to health. ${ }^{185}$ The mention of a collaboration between a business and the State, and of the ultimate responsibility of the State, does temper the horizontal effect within the general comments to some extent though, and (as with General Comment No. 5) cannot be read as imposing direct (and in any case not binding) international obligations on non-State actors. Thus, this Comment remains an example of indirect horizontal effect.

Although the comments thus far have actually been relatively extensive in dealing with non-State actors, a noticeable shift occurred in General Comment Nos. 14 and 15, which include a section specifically entitled 'Obligations of

\footnotetext{
182 UN CteeESCR, 'General Comment No. 12' (n 176).

183 Ibid para. 20.

184 Ibid.

185 UN CteeESCR, 'General Comment No. 14' (n 173) para. 42.
} 
actors other than States'. This suggests that the CteeESCR does in fact envisage more direct, and possibly even binding, human rights obligations for non-State actors. In the two comments the Committee mentions, for example, obligations of international organisations that have ties with the right to health and water, respectively (naming, for example, the World Health Organization, the Food and Agricultural Organization and UNICEF). ${ }^{186}$ The obligations included mostly involve giving support and aid to States in the implementation of their Covenant rights, although international organisations (including international financial institutions) should also incorporate 'human rights law and principles in the[ir] programmes and policies.' ${ }^{187}$ Although the Committee does actually say that the obligations of the international organisations fall under the scope of human rights obligations, it is significant that in General Comment No. 15 the CteeESCR notes that the cooperation and support of the international organisations will be considered when assessing how capable States are of realising rights within their jurisdiction, ${ }^{188}$ thereby implying that the obligations of the international organisations are related to the realisation of human rights, and could have a bearing on the standards expected of states in terms of their obligation to fulfil human rights. The fact that these obligations are only mentioned as existing for international organisations could be telling here, especially as other non-State actors (e.g. privatised companies) often contribute to the obligation to fulfil human rights by providing certain services without having an obligation to do so. ${ }^{189}$ We normally assume that non-State actors are dealt with within national legal frameworks. However, international organisations, by their nature, operate in the international sphere, and are directly subject to some international laws (although not to date those found in human rights treaties). This makes it less of a stretch to imagine that the CteeESCR was directly involving international organisations in human rights realisation, particularly when the operations of many international organisations are connected to human rights in some way (e.g. the World Bank, or even the UN itself).

Significantly, though, in more recent general comments, the CteeESCR has even taken one step further to say that private actors do actually have an 'obligation' (rather than a responsibility) to respect certain human rights.

186 Ibid, Section 5; Un CteeESCR, 'General Comment No. 15' (n 178) Section VI.

187 Un CteeESCR, 'General Comment No. 14' (n 173) Section 5; un CteeESCR, ‘General Comment No. 15' (n 178) Section vi.

188 Un CteeESCR, 'General Comment No. 15' (n 178) para. 60.

189 See Hesselman and Lane, 'Non-State Actors and Disasters - Human Rights-Based Approaches' (n 172). 
In General Comment No. 22 on the right to sexual and reproductive health, the CteeESCR requires State Parties to avoid taking retrogressive measures that could, inter alia, 'reduce oversight by States of the obligation of private actors to respect the right of individuals to access sexual and reproductive health services' ${ }^{\prime} 90$ The language used here is significant, although admittedly it is not clear whether the 'obligations' envisaged for private actors exist at the national or international level (the assertion having been made in the context of the State's obligation to protect human rights). Although the statement is quite narrow in terms of substance, the broad term 'private actors' suggests that all private actors have an obligation not to interfere with access to sexual and reproductive health services. Whether or not the statements can really be read as an understanding that non-State actors do have human rights obligations, they still cannot result in legally binding obligations at the international level. As explained, general comments do not have a legally binding nature and cannot create obligations themselves, but rather constitute the (arguably authoritative) opinion of the CteeESCR as to what standards the Covenant rights demand.

The CteeESCR has very recently adopted a general comment on business and human rights (General Comment No. 24), ${ }^{191}$ in which it explains in more detail what obligations States have regarding human rights interference by businesses. Interestingly, the comment includes measures under the obligations to respect, protect and fulfil human rights, rather than just the obligation to protect. Although the document is directed predominantly at States, its relevance for 'the corporate sector' is also emphasised, as it seeks to help them 'in discharging their human rights obligations and assuming their responsibilities'. ${ }^{192}$ Although the language of 'obligations' as well as responsibilities here is striking, it is unclear whether the CteeESCR is referring to obligations of businesses at the national or international level, and the CteeESCR later clarifies

190 UN CteeESCR, 'General Comment No. 22 (2016) on the right to sexual and reproductive health (article 12 of the International Covenant on Economic, Social and Cultural Rights)', 2 May 2016, E/C.12/GC/22, para. 38 .

191 UN CteeESCR, 'General Comment No. 24 on State Obligations under the International Covenant on Economic, Social and Cultural Rights in the Context of Business Activities', 10 August 2017, E/C.12/GC/24.

192 Ibid, para. 5. Interestingly, in an earlier draft of the general comment, the CteeESCR had referred to 'non-State actors' rather than the corporate sector, going against its previous trend of referring to 'private actors'. See Un CteeESCR, 'General Comment on State Obligations under the International Covenant on Economic, Social and Cultural Rights in the Context of Business Activities', E/C.12/6-/R.1, draft of 17 October 2016, paras. 5-6. 
that it 'only deals with the conduct of private actors ... indirectly.'193 Of course, the comment is also of interest to individuals seeking redress against States for human rights interference by businesses.

In terms of the obligation to respect human rights, the CteeESCR explains that States could be responsible for violating this obligation due to the 'action or inaction of business actors', which can (following the rules on attribution found in the DASR ${ }^{194}$ ) be attributed to States in certain circumstances, namely:

(a) if the entity concerned is in fact acting on that State party's instructions or is under its control or direction in carrying out the particular conduct at issue, as may be the case in the context of public contracts; (b) when a business entity is empowered under the State party's legislation to exercise elements of governmental authority or if the circumstances call for such exercise of governmental functions in the absence or default of the official authorities; or (c) if and to the extent that the State party acknowledges and adopts the conduct as its own. ${ }^{195}$

This is the first time that the Committee has explicitly referred to the DASR. It seems that for the most part, the monitoring body seems to mention attribution in connection with the obligation to protect human rights, but without explaining how this fits within the framework of the DASR (or indeed whether it actually needs to). The fact that they are quoted in the general comment is therefore significant, and it will be interesting to see whether reference is also made in future general comments.

Following the tripartite typology of human rights, the CteeESCR details what States should do under each category of obligation. Under the obligation to protect human rights, this includes:

- 'prevent effectively infringements of economic, social and cultural rights in the context of business activities' ${ }^{196}$;

- 'adopt legislative, administrative, educational, as well as other appropriate measures to ensure effective protection against Covenant rights violations linked to business activities' ${ }^{\prime 197}$ (e.g. the adoption of criminal sanctions,

\footnotetext{
193 Un CteeESCR, 'General Comment No. 24' (n 191) para. 11.

194 DASR Articles 8, 5 and 9. See Section 3.3 above.

195 CteeESCR, 'General Comment No. 24' (n 191) para. 11.

196 Ibid para. 14.

197 Ibid.
} 
imposing due diligence standards on businesses and conducting 'direct regulation and intervention' where necessary $)^{198}$; and

- to put in place 'effective monitoring, investigation and accountability mechanisms' to enable 'those whose Covenant rights have been violated in the context of business activities' access to effective remedy. ${ }^{199}$

The CteeESCR is explicit in laying down its general understanding of the obligation to protect, which it understands as being violated by 'a failure by the State to take reasonable measures that could have prevented the occurrence' of a violation caused by a private actor, even when the private actor was not the sole cause of the violation and even (as long as it was reasonably foreseeable) when the State did not foresee the violation. ${ }^{200}$ The comment also provides considerable detail regarding precise legislative, administrative and other measures that could or should be adopted (and enforced) by States to regulate and monitor businesses' effects on economic, social and cultural rights in certain contexts (e.g. in relation to the tobacco industry, the housing market, the education and employment sectors, among others). ${ }^{201}$ In this regard the CteeESCR also reiterates the obligation to regulate non-State actors, especially in the context of privatisation and the private provision of public services. ${ }^{202}$ As well as explaining the obligations of States the CteeESCR elaborates on the due diligence standards that States should hold businesses to, including to 'act with due diligence to identify, prevent and address abuses to covenant rights' by their subsidiaries and business partners. ${ }^{203}$ What can be seen from the general comment is that the CteeESCR applies indirect horizontal effect predominantly through States' obligation to protect human rights (including due diligence), but also through attributing non-State conduct to States in certain situations. Interestingly, the other monitoring bodies also tend to mention (without explaining in legal terms) attribution in the context of the obligation to protect.

\footnotetext{
198 See ibid paras. $14-22$.

199 Ibid para. 38.

$200 \quad$ Ibid para. 11.

201 See ibid para. 19.

202 Ibid paras. 21-22. For example, the CteeESCR states that '[p]rivate providers should ... be subject to strict regulations that impose on them so-called "public service obligations"'. ibid para. 21.

203 Ibid para. 33.
} 
4.2.2 Views of the Committee on Economic, Social and Cultural Rights The CteeESCR has the competence to hear individual complaints pursuant to the Optional Protocol to the International Covenant on Economic, Social and Cultural Rights. ${ }^{204}$ However, as the Optional Protocol only entered into force in 2013, there is relatively little jurisprudence from the body as compared to the other UN human rights monitoring bodies. ${ }^{205}$ The communications that have been considered by the Committee so far have not dealt with the horizontal effect of human rights, and will therefore not be discussed here.

\subsubsection{Critical Remarks on the Jurisprudence of the Committee on Economic, Social and Cultural Rights}

Overall, the CteeESCR's general comments are quite telling of its attitude towards indirect horizontal effect. It has repeatedly referred to the State obligation to protect human rights, requiring specific action to be taken to regulate and control the actions of non-State actors, particularly those with a connection to the State (i.e. privatised companies) and actors that have been delegated certain public tasks. The fact that the Committee has adopted comment specifically on business and human rights is significant. Regarding the CteeESCR's interpretation and application of the obligation to protect, the same can be said as for the HRCtee - although there are now detailed recommendations for States to take certain action to protect human rights, it is not clear to which standards exactly non-State actors must be upheld at the national level. What is clear from its general comments is that the CteeESCR has a strong belief that non-State actors do have at least a role, and perhaps even obligations, within the international human rights framework. Thus, while the Committee has mostly confined itself to interpreting ICESCR in a way that results in indirect horizontal effect, it has gone further than the HRCtee in alluding to direct horizontal effect.

Significantly, the Committee has even suggested that some non-State actors have a more active or positive role to play in the realisation of rights, with an obligation to help States with their own implementation. This already pushes the boundaries of the international human rights framework, which does not envisage human rights obligations for non-State actors. Getting to the point

204 Optional Protocol to the International Covenant on Economic, Social and Cultural Rights, General Assembly Resolution 63/117, 5 March 2009, A/REs/63/117.

205 Ibid. Despite being adopted in 2009, the Protocol lacked sufficient ratifications to enter into force until 5 May 2013. See the website of the онCHR. 'Monitoring the economic, social and cultural rights'. Retrieved 24 October 2017 www.ohchr.org/EN/HRBodies/CESCR/ Pages/CESCRIntro.aspx. 
where the Committee could legitimately (i.e. within its mandate) and explicitly detail human rights obligations for non-State actors (beyond those to be imposed within domestic law) would require a change of the international legal framework. For such statements to have a practical effect, State Parties to ICESCR would then need to act upon them. Of course, in theory, the Committee could choose to go down this road without a change in the framework or its mandate, but this is likely to be met with much resistance from disgruntled States that could choose to simply ignore the CteeESCR. Until the international human rights framework is expanded from a State-centric system, or alternatives are found outside of the legal framework, it is unlikely that more horizontal effect will be achieved in relation to the Covenant on Economic, Social and Cultural Rights.

\subsection{Committee on the Elimination of Discrimination against Women}

The Committee on the Elimination of all Forms of Discrimination Against Women (CteeEDAW) has also faced situations necessitating an application of horizontal effect of human rights. The following sections will assess the extent to which the CteeEDAW has applied this obligation in practice, looking first at its general recommendations before discussing its relevant jurisprudence.

\subsubsection{General Recommendations of the Committee on the Elimination of Discrimination against Women}

Significantly, non-State actors are mentioned explicitly in the Convention on the Elimination of All Forms of Discrimination Against Women (CEDAW) itself. Article 2(e) of the Convention imposes a general obligation on State Parties to 'take all appropriate measures to eliminate discrimination against women by any person, organization or enterprise..206 General Recommendation No. 28 on the core obligations of State parties under Article 2 affirmed that the provision embodies a positive obligation for States to ensure that women are not subject to discrimination by non-State actors, including by 'national corporations operating extraterritorially' (i.e. similarly to the standards upheld

206 Convention on the Elimination of All Forms of Discrimination Against Women (18 December 1979, entered into force 3 September 1981) United Nations Treaty Series, vol. 1249, 13 [emphasis added]. The importance of this provision was most recently intimated by the Un Committee on the Elimination of all Forms of Discrimination Against Women (CteeEDAW) in the case of Angela González Carreño v. Spain, Communication No. 47/2012, 16 July 2014, para. 9.6. 
in the Trail Smelter case regarding transboundary harm). ${ }^{207}$ In this Recommendation, the CteeEDAW also mentioned the attribution of non-State actors' conduct to the State in some situations, although it did not explain when this would be the case or refer to the DASR. Rather, it simply noted that States are 'thus' obliged to take 'appropriate measures', including 'the regulation of the activities of private actors with regard to education, employment and health policies and practices, working conditions and work standards, and other areas in which private actors provide services or facilities, such as banking and housing. ${ }^{208}$ Again, this seems to either conflate 'attribution' as a concept within public international law with the obligation to protect, or to use it as a separate term. The approach of the CteeEDAW in this respect is unclear. As with the CteeESCR, the obligation to regulate is clear here, and seems to apply to all private actors that are providing services of a public nature.

Similar obligations were mentioned in CteeEDAW's General Recommendation No. 19 on violence against women. In this recommendation the CteeEDAW emphasised the importance of States 'tak[ing] appropriate and effective measures to overcome all forms of gender-based violence, whether by public or private acts. ${ }^{209}$ It had previously emphasised that discrimination against women 'is not restricted to action' by State actors, but that 'States may also be responsible for private acts' if they do not act with due diligence. ${ }^{210}$ Indeed, the general recommendation lists instances in which violence against women can 'result from the acts or omissions of State or non-State actors', including, inter alia, where a State has delegated public tasks, e.g. security within places of detention, to private actors. ${ }^{211}$ In specific recommendations, the Committee suggested action that States should take relating to particular non-State actors, such as the media, people in the workplace and family members. The measures to be taken included the adoption and implementation of legislation, provision of services, and other 'preventive, punitive and remedial measures' which States should report to the Committee about. ${ }^{212}$ The wording here suggests that taken together, the measures in the recommendations would constitute the precise

207 UN CteeEDAW, 'General Recommendation No. 28 on the Core Obligations of States Parties under Article 2 of the Convention on the Elimination of All Forms of Discrimination against Women', 16 December 2010, CEDAW/C/GC/28.

208 Ibid.

209 UN CteeEDAW, General Recommendation No. 19:Violence against women', in UN CteeEDAW, 'General Recommendations Nos. 19 and 20, adopted at the Eleventh Session, 1992 (contained in Document A/47/38)' 1992, para. 24(a).

210 Ibid para. 9.

211 Ibid para. 12 [emphasis added].

212 Ibid para. 24. 
standards of due diligence expected by the CteeEDAW. The Committee also mentioned due diligence in Recommendation No. 19 in its explanation of how the State could be held responsible for the conduct of non-State actors (i.e. when they fail to 'act with due diligence to prevent violations of rights or to investigate and punish acts of violence, and for providing compensation'213). Interestingly, in this instance, the CteeEDAW explained such responsibility without mentioning attribution.

In General Recommendation No. 24, the CteeEDAW (like the HRCtee and the CteeESCR), expressed concern about States trying to pass their human rights obligations to private actors when States delegate what are traditionally public functions to these actors. ${ }^{214}$ The CteeEDAW reiterated the opinion of the HRCtee and the CteeESCR that States 'cannot absolve themselves of responsibilities' by delegating public tasks. ${ }^{215}$ This has the effect of ruling out any direct horizontal effect of human rights contained within CEDAW that would occur if responsibility could be passed onto the non-State actors. However, the widespread concern of harmful actions of private actors operating in the 'public' sphere also serves to emphasise and recognise the impact that such non-State actors can have on human rights. Still, though, there is no explanation of what substantive obligations States should impose on nonState actors in order to ensure that they do not cause harm to individuals' human rights. The CteeEDAW's unease also reflects qualms regarding the attitude of States (although no examples were provided by CEDAW), that delegating functions to private actors would mean that the State no longer has to deal with the human rights aspects related to that function. What is not addressed by the CteeEDAW, or indeed the other monitoring bodies addressed so far, is the possibility of concurrent or shared responsibility for non-State actors that are delegated State functions - it could be possible for both the State to retain responsibility as well as confer a degree of responsibility on the non-State actor. ${ }^{216}$ So far, as we have seen with the two previous treaty bodies discussed, this has only been deemed to be appropriate at the national, and not the international, level. Indeed, at the international level it is not considered possible for States to 'replac[e], legally delegat $[\mathrm{e}]$ or chang[e]'

\footnotetext{
213 Ibid para. 9.

214 UN CteeEDAW, 'General Recommendation No. 24: Article 12 of the Convention (Women and Health)', 1999, A/54/38/Rev.1, chap. I, para. 17.

215 Ibid.

216 A discussion of 'shared responsibility' of international legal obligations falls outside of the scope of this article. In-depth research into this notion has been carried out by the SHARES Project (n 84).
} 
their de jure responsibility when they outsource certain tasks to non-State actors. ${ }^{217}$

Further explanation of the State obligation to protect women was provided in General Recommendation No. $34 .{ }^{218}$ The CteeEDAW adopted the same approach as the CteeESCR by imposing an obligation to 'regulate the activities of domestic non-State actors within their jurisdiction, including when they operate extraterritorially.'219 Specifically, reiterating its General Recommendation No. 28, the CteeEDAW requests States to 'prevent any actor under their jurisdiction, including private individuals, companies and public entities, from infringing or abusing the rights of rural women outside their territory' ${ }^{220}$ As well as the obligation to regulate, General Recommendation No. 34 includes implicit reference to due diligence vis-à-vis non-State actors, requiring States to ' $\mathrm{t}]$ ake effective measures aimed at preventing, investigating, prosecuting and punishing acts of violence against rural women and girls, including migrant rural women and girls, whether perpetrated by the State, non-State actors or private persons. ${ }^{221}$ Similar to its approach in Recommendation No. 19, the CteeEDAW goes on to elaborate more precise recommendations to protect human rights and uphold due diligence (this time, in relation to different subject areas, e.g. 'adequate living conditions').222

While the obligation to protect is paramount in situations where private actors carry out State functions (and indeed more generally in the purely 'private' sphere as well), the indirect horizontal effect being applied unfortunately does not go very far in preventing human rights interference by actors outside of the control of the State, in situations where domestic law and policies are not effective in manipulating the behaviour of private actors (as explained in Section 3.3.1, due diligence is an obligation of conduct, not result). Interestingly though, in General Recommendation No. 25, the CteeEDAW noted that merely averring 'powerlessness' or succumbing to 'predominant market or political forces' is not enough for States to justify a failure to fulfil their obligation to

217 See Lane and Hesselman, 'Governing Disasters' (n 86) 93, referring to I. Brownlie, 'State responsibility: The problem of delegation', in: K. Ginther et al. (eds) Völkerrecht Zwischen Normativem Anspruch und Politischer Realität (Berlin: Duncker \& Humblot, 1994) 300-330; and Lane, 'Private providers of essential public services and de jure responsibility for human rights' (n 45).

218 UN CteeEDAW, 'General Recommendation No. 34 (2016) on the rights of rural women', 7 March 2016, CEDAW/C/GC/34.

219 Ibid para. 13.

220 Ibid.

221 Ibid para. 25 (b) [emphasis added].

222 See ibid para. 80. 
protect women's rights from the actions of private actors. ${ }^{223}$ In doing so, the Committee reaffirms that CEDAw holds States accountable for the actions of private actors such as businesses, which are in a position to assert influence over the State. ${ }^{224}$

Further reiteration of this, provided in some detail, can be found in the CteeEDAW's General Recommendation No. 30. ${ }^{225}$ This Recommendation deals with the treatment of women during and after armed conflicts, and goes quite far in detailing the obligations of States to act with due diligence as well as (crucially) the behaviour expected of non-State actors towards women during these times. ${ }^{226}$ Such recommended action includes refusing to reduce the protection afforded to women in order to mollify non-State actors, ${ }^{227}$ engaging with non-State actors, ${ }^{228}$ and helping non-State actors to act in a manner consistent with the Convention, in particular to 'address and assess' risks of human rights violations. ${ }^{29}$ This standard could also be included, for example, in the codes of conduct of businesses alluded to by the CteeESCR above. The context of armed conflict here arguably allows the CteeEDAW to go further in describing the obligations of non-State actors, because under international humanitarian law non-State actors are subject to direct obligations. ${ }^{230}$ Breaches of some of these obligations, as well as 'gross violations of human rights' by non-State actors (an anomaly in terms of language), can result in these actors being held (individually) criminally responsible at the international level. ${ }^{231} \mathrm{By}$ mentioning these obligations and the connections that can be made between international humanitarian and human rights law during armed conflicts, the CteeEDAW allowed itself space to mention the human rights obligations of

223 UN CteeEDAW, 'General Recommendation No. 25, on article 4, paragraph 1, of the Convention on the Elimination of All Forms of Discrimination against Women, on temporary special measures', 2004, para. 29.

224 Ibid para. 29. Referring here to Article 2 of the Convention, which deals with the nature of States' obligation under the treaty.

225 UN CteeEDAW, 'General Recommendation No. 30 on women in conflict prevention, conflict and post-conflict situations', 1 November 2013, CEDAW/C/GC/30.

226 Including in the duty of due diligence the provision of redress by the State for the 'acts of private individuals or entities'. See ibid para. $17(\mathrm{a})$.

227 Ibid para. 17 (b).

228 Ibid para. 17 (c).

229 Ibid para. $17(\mathrm{~d})$.

230 As noted by the Un CteeEDAW, ibid para. 16.

231 See Un онCHR. 2011. 'International Legal Protection of Human Rights in Armed Conflict' HR/PUB/11/o1, 26. Retrieved 7 November $2017<$ www.ohchr.org/Documents/Publications/ HR_in_armed_conflict.pdf $>$. 
non-State actors during (or after) armed conflicts in their own right. The actors specifically targeted by the Recommendation were non-State armed groups, ${ }^{232}$ which the CteeEDAW explicitly noted as having an obligation to respect human rights (particularly when they have an 'identifiable political structure' and 'significant control over territory and population'). ${ }^{233}$ Notably, this assertion was made after the CteeEDAW acknowledged the fact that non-State actors cannot become party to international human rights treaties. ${ }^{234}$ Unfortunately though, the strength of the comments is diminished by the lack of legal basis provided by the CteeEDAW to justify how non-State actors could be said to hold these obligations. Nevertheless, the Committee continued not only to make recommendations to States in the general recommendation, but also directly to nonState actors. For example, besides calling on non-State armed groups to respect women's rights, ${ }^{235}$ the CteeEDAW (like the CteeESCR did in relation to private providers of public services),, ${ }^{236}$ suggested that the groups 'commit themselves to abide by codes of conduct on human rights.' ${ }^{237}$ Again, the common downfall of treaty bodies' documents comes into play here, and the non-binding nature of General Recommendation No. 30 significantly reduces the impact that the recommendations may have in practice. Yet, the statements clearly show that the CteeEDAW is willing to entertain the notion of at least human rights responsibilities for certain non-State actors.

\subsubsection{Views of the Committee on the Elimination of Discrimination against Women decisions}

Many of the complaints filed with the CteeEDAW involve action taken by nonState actors as well as (inaction) by State actors. For reasons of space, some examples will be chosen which show clearly the ways in which the CteeEDAW engages with the private sphere and interference with human rights by nonState actors. The cases used rely to some extent on the provision in Article 2(e) CEDAW, which requires States to eliminate discrimination against women by private as well as public actors.

232 Although the CteeEDAW also mentioned 'paramilitaries, corporations, private military contractors, organized criminal groups and vigilantes' as actors that could affect the human rights enjoyment of women during or after armed conflicts. See Un CteeEDAW, 'General Recommendation No. 30' (n 225) para. 13.

233 Ibid para. 16.

234 Ibid para. 16.

235 Ibid para. $18(\mathrm{a})$.

236 See un CteeESCR, 'General Comment No. 12' (n 176) para. 20.

237 UN CteeEDAW, ‘General Recommendation No. 30’ (n 225) para. 18(b). 
First, the application of due diligence by the CteeEDAW can be clearly seen in its jurisprudence relating to domestic violence suffered by women at the hands of private actors. The vast majority of the cases before the CteeEDAW involving horizontal effect concern instances of domestic violence, and failures of the State Party to provide effective protection for women from (for example) their partners. An oft-quoted example of this is the case of A.T. v. Hungary. ${ }^{238}$ In this case the Committee explicitly adopted the tripartite typology of human rights and the duty of due diligence. ${ }^{239}$ The author of the complaint had repeatedly suffered domestic abuse and threats had been made against her children by her former partner. Despite the author bringing several civil and criminal proceedings against the husband, the Hungarian State had failed to protect both her and her children. ${ }^{240}$ Quoting its comments in General Recommendation No. 19 on due diligence, the Committee found Hungary to have violated the woman's rights due to its failure to effectively protect her from her former common law husband. ${ }^{241}$

A similar conclusion was reached by the CteeEDAW in the recent decision of Angela González Carreño v. Spain, ${ }^{242}$ in which the author had also suffered repeated abuse at the hands of her partner, culminating in the murder of her daughter by him. ${ }^{243}$ The Committee's focus in this case was also on due diligence, looking specifically at Spain's failure to conduct an investigation or inquiry into the situation being suffered by the author and her daughter and failing to provide adequate supervision, despite over thirty complaints and requests made by the author to the State asking for protection. ${ }^{244}$ Rather than fulfilling its duty of due diligence, the CteeEDAW found that Spain had made assumptions without analysing the specific situation of the author. In the context of the complaints made by the author in this case, the Committee's approach could be compared to the aspect of 'foreseeability' of harm by a non-State actor, as explained in Section 3.3.1. For example, the murder of the child occurred during an unsupervised visit of the abusive partner, which the domestic court had granted following its assumption that it was always better for children to have contact with their father, ignoring (or deeming irrelevant) the abusive history of this particular father. In this case, as well as previous

\footnotetext{
238 A.T. v. Hungary (2/2003), CEDAW, A/6o/38 Part I (26 January 2005).

239 Ibid paras. II (a) and II (b), respectively.

240 Ibid paras. 2.1-2.7; 9.4-9.5.

241 Ibid paras. 9.2-9.5.

242 Angela González Carreño v. Spain (n 206).

243 Ibid para. 3.2.

244 Ibid para. 9.9.
} 
cases, the CteeEDAW went on to provide specific action that should be taken by the respondent State in order to fulfil its positive obligations under the Convention in the future (as well as measures to provide the author with redress). For example, the Committee requested that Spain '[s]trengthen application of the legal framework to ensure that the competent authorities exercise due diligence' and '[c]onduct an exhaustive and impartial investigation'. This emphasis on investigations was also apparent in A.T. v. Hungary, with CteeEDAW requesting Hungary to '[i]nvestigate promptly, thoroughly, impartially and seriously all allegations of domestic violence and bring the offenders to justice.'245 As the HRCtee and CteeESCR, the CteeEDAW appears to focus mostly on the State's procedural obligations under the obligation to protect, again limiting the extent to which its approach can really be considered to be one of 'indirect horizontal effect'.

Outside of the context of domestic violence, the CteeEDAW has also applied a duty of due diligence. As the HRCtee and the CteeESCR, the CteeEDAW has used the duty of due diligence to attribute the actions of private providers of public services to the State and find a violation of rights within CEDAW. In Alyne da Silva Pimentel Teixeira (deceased) v. Brazil, for example, a complaint was brought on behalf of a woman who had died in a private health institution during her pregnancy. The Brazilian State tried to argue that because the health institution was a private actor, its

professional negligence, inadequate infrastructure and lack of professional preparedness' could not be attributed to the State. ${ }^{246}$ However, Brazil did acknowledge 'shortcomings in the system used to contract private health services and, by extension, the inspection and control thereof'. The Committee used this to find that Brazil had failed to fulfil its duty of due diligence in line with Article 2 CEDAw. ${ }^{247}$ The CteeEDAW also reiterated its position taken in previous decisions and general recommendations that 'the State is directly responsible for the action of private institutions when it outsources its medical services' and 'always maintains the duty to regulate and monitor private health-care institutions.'.48 In other words, Brazil could not delegate its legal responsibility for the protection of human rights through the act of delegating certain

\footnotetext{
245 A.T. v. Hungary (n 238).

246 Alyne da Silva Pimentel Teixeira (deceased) v. Brazil, Communication No. 7/2008 (2011), para. 7.5. For discussion see L. Hodson, 'Women's Rights and the Periphery: CEDAw's Optional Protocol', European Journal of International Law 25(2) (2014) 561 at 570-571.

247 Alyne da Silva Pimentel Teixeira (deceased) v. Brazil (n 246) para. 7.6.

248 Ibid.
} 
public services (i.e. healthcare) to private institutions. Again, we see here reference to an obligation to regulate privatised services.

\section{$4 \cdot 3 \cdot 3$}

Critical Remarks on the Jurisprudence of the Committee on the Elimination of Discrimination against Women

We can see from the above examples that the approach of the CteeEDAW in its views on individual complaints mirrors its approach taken in General Recommendations. Perhaps because of the wording of Article 2 of the Convention, the CteeEDAW has not wavered in States' positive obligations in order to lend more protection to women, particularly from situations of domestic violence. Further, it has repeatedly stressed the appropriate measures that State Parties must take to observe its duty of due diligence for what concerns 'purely' private relationships (e.g. between two or more individuals) and 'quasi-public' relationships (e.g. between an individual and a private public service provider). As did the CteeESCR, the CteeEDAW also examined, to a limited extent, more direct obligations of non-State actors. Its comments on non-State armed groups in General Recommendation No. 30 show that in some situations (primarily, when a group has effective control over some territory), non-State armed groups may have direct responsibilities to at least respect human rights both during and after armed conflicts.

\subsection{Committee against Torture}

The fact that the UN Committee against Torture (CteeAT) has given any attention to the application of the UN Convention against Torture (САT) between non-State actors is extremely interesting in light of the definition of torture provided in the СAT. ${ }^{249}$ Article 1 CAT appears to explicitly rule out the possibility that torture could be committed by a private person without any involvement of the State. The definition includes as a criterion that an act be committed 'at the instigation of or with the consent or acquiescence of a public official or other person acting in an official capacity' for it to be torture. The same criterion applies in relation to acts of cruel, inhuman or degrading treatment, which is prohibited by Article 16 сат. ${ }^{250}$

249 Convention Against Torture and Other Cruel, Inhuman or Degrading Treatment or Punishment (1o December 1984, entered into force 26 June 1987) United Nations Treaty Series, vol. 1465,85 .

250 Although the distinction between torture and cruel, inhuman and degrading treatment is clear in the CAT, it will not be dwelt upon here. As both prohibitions share the requirement of the involvement of a public actor, the following discussions will refer to cases involving both Article 1 and Article 16 cAT. 
From this wording, we could assume that the direct horizontal effect of torture can be prima facie ruled out (as suggested by Alice Edwards). ${ }^{251}$ However, it does not seem to preclude the possibility of some forms of indirect horizontal effect, relying on State's positive obligations and attributing the actions of a non-State actor to the State. In the context of Articles 1 and 16 CAT this would most obviously be through a private actor acting under the instruction of, with the consent of, or at the acquiescence of a public actor. As Article 1 is prohibitive and therefore inherently negative in nature, it may be argued that Article 1 CAT also does not, prima facie, give rise to a positive State obligation to protect which would allow the CteeAT to invoke indirect horizontal effects in its views on individual communications. ${ }^{252}$ Additionally, as a civil and political, rather than an economic, social or cultural right, some may try to argue that the tripartite typology of human rights does not apply to the prohibition of torture, as it only concerned negative obligations. A related argument was made above by the us regarding positive obligations under the prohibition of torture in the ICCPR (Section 4.1.1). The likely success of such an argument is now very low. As Magdalena Sepùlveda notes, "[t]oday it is beyond doubt that civil and political rights instruments [...] also impose "positive obligations" on the part of States Parties which are often not explicitly contained in the text' ${ }^{253}$ - 'attempting to classify every right as either flatly negative or positive, is an "artificial, simplistic and arid exercise".'254

Indeed, the Committee has been willing to openly apply Article 1 in such a way as to allow indirect horizontal effect of the prohibition using the State's responsibility to protect individuals from harmful actions by non-state actors. The Committee has also allowed for indirect horizontal effect by treating some non-State actors as State actors by virtue of them carrying out particular 'governmental' functions. As was the case with the treaty monitoring bodies examined above, the following examination will look firstly at the Committee's general comments and then the jurisprudence arising from its views on

251 A. Edwards, 'The 'Feminizing' of Torture under International Human Rights Law', Leiden Journal of International Law 19(2) (2006) 349 at 371.

252 Such individual communications may only be brought against a State Party to the CAT that has made a declaration under Article 22 of the CAT to the effect that it 'recognizes the competence of the Committee to receive and consider communications from or on behalf of individuals subject to its jurisdiction who claim to be victims' of a violation of the CAT by that State Party.

253 M. Sepùlveda, The Nature of Obligations under the International Covenant on Economic, Social and Cultural Rights (Antwerp: Intersentia, 2003) 124.

254 Ibid, quoting H. Shue, 'The interdependence of duties', in: P. Alston and K. Tomaševski (eds) The right to food (Utrecht: Martinus Nijhoff Publishers, 1984) 84. 
individual complaints, to determine how the CteeAT understands the obligations in the CAT vis-à-vis non-State actors.

\subsubsection{General Comments of the Committee against Torture}

The attitude of the Committee against Torture (CteeAT) towards horizontal effect initially appeared quite limited. In its first general comment adopted in 1998, the CteeAT emphasised the importance of the public official criterion, and did not mention private actors. ${ }^{255}$ In its second comment, however, the Committee paid more attention to the acts of non-State actors, in particular the due diligence obligations of States. The CteeAT held the due diligence obligation to apply in instances where States know or have reasonable grounds for believing' that non-State actors are committing torture or acts of ill-treatment. ${ }^{256}$ The rationale of the Committee here is that because of the wording of Article 1, States must be under a positive obligation to protect individuals from torturous acts by non-State actors. The 'consent or acquiescence' of the State essentially means that if a State fails to take positive measures to protect individuals, it is implicitly permitting, or acquiescing to the harm by the non-State actor. ${ }^{257}$ This interpretation has vastly changed the landscape of the prohibition of torture within international law, and is also applied by other human rights monitoring bodies (in particular regional human rights courts). ${ }^{258}$

\subsubsection{Views of the Committee against Torture}

The interpretation and its application by the CteeAT in its own views on individual complaints undoubtedly affords broader protection to individuals. However, the CteeAT has not actually applied horizontal effect to the full potential allowed by Article 1. Certainly, it is positive that the Committee has addressed the duty of due diligence explicitly, but its interpretation of State

255 UN Committee Against Torture (CteeAT), 'General Comment No. 1: Implementation of Article 3 of the Convention in the Context of Article 22 (Refoulement and Communications)', 21 November 1997, A/53/44, annex IX.

256 UN CteeAT, 'General Comment No. 2: Implementation of Article 2 by States Parties', 24 January 2008, CAT/C/GC/2, para. 18.

257 See ibid.

258 The European Court of Human Rights, for example, adopts the CAT's definition of torture and has repeatedly taken the approach that the prohibition of torture includes positive, protective State obligations. See e.g. A. v. United Kingdom (1998), 27 EHR 611, para. 22; Z. and Others v. United Kingdom Application No. 29392/95 (2001), paras. 73-75; and E. and Others v. United Kingdom, Application No. 33218/96 (2002); M.C. v. Bulgaria, Application No. $39272 / 98$ (2003). 
'consent or acquiescence' is actually relatively limited. ${ }^{259}$ For example, in the case of S.V.et al. v. Canada, ${ }^{260}$ the Committee dealt with complaints relating to torture by the Liberation Tigers of Tamil Elam (LTTE) in Sri Lanka. The author feared that if he were to return to Sri Lanka, he would be subjected to torture either by the LTTE, or by the State (whom he argued had caused him brain damage on an earlier occasion following allegations by the State that he was actually a member of LTTE). The Committee clearly held any consideration of torture by the LTTE with no consent or acquiescence of the State to fall outside of the scope of the САт. ${ }^{261}$ However, it did not provide indications as to what actions they believed could constitute consent or acquiescence. Nevertheless, Edwards has deducted from this case, along with that of G.R.Bv. Sweden (below, also dealing with torture by non-State actors) that the CteeAT sees 'consent and acquiescence' as amounting to either some knowledge on behalf of the State of the actions by the non-State actor, the State being in 'general agreement' with them, or purposefully refusing to act against them. ${ }^{262}$ This seems to be consistent with the application of due diligence by the previous bodies discussed, although narrower than the obligation to protect more generally. It is unclear whether the knowledge on behalf of the State would also require State investigations into the actions of non-State actors (as is the case with due diligence under other bodies), or refers solely to information provided to the State by the non-State actors themselves.

One major issue that surfaces repeatedly in individual complaints relating to torture is that of women being raped by private individuals. Interestingly, the cases in relation to which these comments have been made do not usually include any involvement of public officials, making them noteworthy studies of whether and how horizontal effect has been applied in practice. Furthermore, these cases demonstrate the limitations in the way that the CteeAT looks upon due diligence.

Since 1986, UN special rapporteurs have defined rape as constituting torture. ${ }^{263}$ The UN has also noted that in the last few decades, 'significant

259 K. Fortin, 'Rape as Torture - An Evaluation of the Committee against Torture's attitude to sexual violence', Utrecht Law Review 4(3) (2008) 145 at 153. See also R. McCorquodale, and R. La Forgia, 'Taking off the Blindfold: Torture by Non-State Actors', Human Rights Law Review $1(2)$ (2001) 189 at 206.

26o Un CteeAT, S.V. et al. v. Canada, CAT/C/26/D/49/1996, 15 May 2001.

261 Ibid para. 9.5.

262 Edwards, 'The 'Feminizing' of Torture under International Human Rights Law' (n 251) 372.

263 See E. Smith, A legal analysis of rape as torture in the international and regional (non -European) fora, in M. Peel (ed) Rape as a Method of Torture (Medical Foundation for the Care of Victims of Torture, 2004) 167 at 189. 
efforts' have been made to 'redefine the meaning of human rights'264 in order to answer the feminist critique of those such as Hilary Charlesworth, Christine Chinkin and Shelley Wright that the prohibition of torture is inherently biased against women. ${ }^{265}$ This is largely due to the fact that the majority of rapes of women happen within private relationships (being, for example, aspects of situations of domestic violence). ${ }^{266}$ In consequence, several bodies have now held that rape may constitute torture 'per se,,267 and will always meet the 'minimum threshold' required to engage provisions prohibiting torture. ${ }^{268}$

In the case of G.R.B v. Sweden, ${ }^{269}$ the author of the complaint feared being subjected to torture by both State and non-State officials upon her return to Peru after having three applications for asylum in Sweden rejected. The fear stemmed from previous instances in which the author was kidnapped and raped by a terrorist organisation in Peru, and the fact that she and her family had been politically active against the Peruvian State in the past, with her father already having been tortured by State authorities. The CteeAT held that the fact that an individual 'might risk pain or suffering inflicted by a nongovernmental entity, without the consent or acquiescence of the Government, falls outside the scope of $[\ldots]$ the Convention.270 The risk of torture by the Peruvian State itself was ruled out by the Committee, mainly because the author had not been politically active for 13 years, and that she had never been subjected to torture by the Peruvian authorities in the past. ${ }^{271}$ The author's complaint was therefore unsuccessful. Unfortunately, the CteeAT did not

264 See Report of the Secretary-General, which was submitted pursuant to the Commission Resolution 1998/29, 18 December 1998, UN Doc. E/CN.4/1999/92, para. 12, cited in McGlynn, 'Rape, Torture and the European Court of Human Rights' (n 4) 594.

265 See H. Charlesworth, C. Chinkin and S. Wright, 'Feminist Approaches to International Law', American Journal of International Law 85 (1991) 613 at 628.

266 See Office of Justice Programs, National Institute of Justice, 'Victims and Perpetrators'. Retrieved 26 October 2017 www.nij.gov/topics/crime/rape-sexual-violence/Pages/victimsperpetrators.aspx.

267 For example, the African Commission of Human Rights in Malawi African Association and Others v. Mauritania, Comm. Nos. 54/91, 61/91, 98/93, 164/97 à 196/97 and 210/98 (2000), para. 118; European Court of Human Rights, Aydin v. Turkey, Application No. 57/1996/676/866, 25 September 1997, para. 86 .

268 E.g. International Criminal Tribunal for the Former Yugoslavia, Prosecutor v. Delalic and others, Case No IT-96-21-A (2001); European Court of Human Rights, M.C. v. Bulgaria, (n 258) discussed in C. McGlynn, 'Rape, Torture and the European Court of Human Rights', The International and Comparative Law Quarterly 58(3) (2009) 565 at 571-572.

269 Un CteeAT, G.R.B v. Sweden, CAT/c/20/D/083/1997, 15 May 1998.

270 Ibid para. 6.5.

271 Ibid paras. 6.4 and 6.6. 
assess Peru's investigations into the occurrence of rape that the victim suffered at the hands of the non-State actor, having failed to detail what standards the Peruvian State would have to fulfil to be acting with due diligence. This could imply that the CteeAT does not understand the CAT as meaning that States Parties are obligated to perform investigations into harm caused by non-State actors. ${ }^{272}$ Indeed, on a literal reading of the Convention and combined with the State actor requirement in Articles 1 and 16, this is understandable, particularly in light of Article 12 CAT. Article 12 places a duty on States to ensure 'prompt and impartial' investigations by 'competent authorities' when an act or torture can reasonably be believed to have been committed within their jurisdiction. Taking this on face value, it does not appear to place any obligations on States to investigate acts conducted by private individuals. Reading Article 12 consistently with CteeAT's interpretation of Article 1, however, the obligation to investigate would equally apply where the act of torture reasonably believed to have been committed would be by a private actor, as well as a public official. Indeed, as we have already seen, other human rights bodies have used the duty of due diligence to impose investigative obligations on States without explicit mention of private actors in the relevant treaty provisions. This is also true specifically in relation to the prohibition of torture, which the European Court of Human Rights understands as requiring States to investigate private acts of torture. ${ }^{273}$

One case in which the relevant State Party (Serbia and Montenegro) was found responsible for not protecting an individual from inhuman or degrading treatment or punishment by private actors was Hajrizi Dzemajl et al. v. Serbia and Montenegro. ${ }^{274}$ The complaint concerned a group of Romani individuals who, following an incident in which a non-Romani girl had been raped by other Romani individuals, were subject to severe violence by a large group of non-Romani citizens. The group of individuals made threats to the Romani, who were advised by police to leave their homes. After the group began setting the Romani individuals' homes on fire and hazing them to the ground, the complainants managed to escape, although some of them had been hiding in

272 Edwards, 'The 'Feminizing' of Torture under International Human Rights Law' (n 251) 371.

273 See M.C. v. Bulgaria (n 258) para. 36, where the Court upheld an obligation to conduct an official investigation into private acts of rape, the effectiveness of which the Court may then assess. See for discussion L. Hasselbacher, 'State Obligations Regarding Domestic Violence: The European Court of Human Rights, Due Diligence, and International Legal Minimums of Protection', Northwestern University Journal of International Human Rights 8 (2009) 190.

274 Un CteeAT, Hajrizi Dzemajl et al. v. Serbia and Montenegro, CAT/c/29/D/161/2000, 21 November 2002. 
the basement of their houses when the violence began. The State authorities had been informed of the action being taken, but 'did not take any appropriate steps in order to protect the complainants, thus implying "acquiescence"' of the State. ${ }^{275}$ In its finding of a violation of Article 16 CAT, the CteeAT explicitly stated that '[a]lthough the acts referred to by the complainants were not committed by public officials themselves, the Committee considers that they were committed with their acquiescence.' ${ }^{276}$ The CteeAT did not go so far as to explain in general what suffices for actions of non-State actors to be attributed to the State due to the latter's 'consent or acquiescence' - does it require that the State actually knew about the risk to the complainants, as in this case, or is it sufficient that the State should have known, as is the standard followed by the European Court of Human rights and the Inter-American Court of Human Rights?277

A second approach towards horizontal effect can be found in the CteeAT's jurisprudence, this time treating some non-State actors as public actors according to the functions that they are fulfilling within a State. This approach was famously taken in the case of Sadiq Shek Elmiv. Australia. ${ }^{278}$ The claimant in this case was a Somali national at risk of being transferred to Somalia by the Australian Government. He argued that by transferring him to Somalia, Australia would be breaching the rule of non-refoulement enshrined in Article 3 СAт. ${ }^{279}$ This rule stipulates that individuals may not be extradited or transferred to a country where they would be at 'real risk' of being subjected to torture. A pivotal factor in this case was that the actor at whose hands the claimant feared being subjected to torture upon his return to Somalia was the Somali Hawiye clan, a non-State armed group. ${ }^{280}$ The nature of cases of nonrefoulement is rather special, in that to find a violation of torture by the responding State does not require this State to actually commit acts of torture. Simply putting the claimant in a situation where he is at risk of being subject to torture by transferring him to a second State is enough for the respondent State to violate the prohibition. If torture were to be committed within the destination State, that State could then also be held responsible (assuming that State

\footnotetext{
275 Ibid para. 9.2.

276 Ibid.

277 See e.g. European Court of Human Rights, Osman v. United Kingdom, Application No. 87/1997/871/1083, 28 October 1998; Z. and Others v. United Kingdom (n 258); Kaya v. Turkey Application No. 22729/93, 19 February 1998. See also Fortin, 'Rape as Torture' (n 259) 156.

278 un CteeAT, Sadiq Shek Elmi v. Australia, CAT/C/22/D/120/1998, 25 May 1999.

279 Ibid para. 3.1.

280 Ibid.
} 
is also party to the CAT). The consequence for horizontal effect in cases like Elmi is not a finding that a non-State actor did/not violate the prohibition of torture itself, but can result in a finding that the acts of a non-State actor could amount to torture, were they to be committed against the claimant after their arrival in the destination State.

The Elmi case is very important here because, despite not involving a claim of torture directly against a non-State actor, the CteeAT acknowledged that actions by non-State armed groups could amount to torture, fulfilling the requirement of State involvement. This was because the non-State armed group in question was 'exercising certain prerogatives that [were] comparable to those normally exercised by legitimate governments'. ${ }^{281}$ This seems quite a progressive move by the Committee. Indeed, treating a non-State armed group as a State actor goes further than any of the approaches seen thus far, but the special circumstances of the case demonstrate that in order to protect the applicant, the CteeAT did not have much choice in its approach. At the time, there were several clans in Somalia vying for State control, each having 'prescribed its own laws and law enforcement mechanisms and [having] provided their own education, health and taxation system' ${ }^{282}$ The ultimate lack of control by the State itself over these established groups seems to have been instrumental in the CteeAT's decision. In contrast, even the abovementioned cases that considered the public function of a non-State actor to be decisive in attributing their actions to the State relied (at least partially) on the fact that the functions had been delegated to the non-State actor in order to find a human rights violation. However, in the Elmi case, it was not a public function that the non-State actor was fulfilling on behalf of the State (as in the cases concerning privatised public services), but a wide range of public activities that the group had taken upon itself in the context of a failed State. The lack of a stable State authority meant that indirect horizontal effect through Somalia's obligation to protect human rights was not possible; the only avenue open to the CteeAT to prevent the transferral was to find a way to categorise the non-State actor as a State actor for the purposes of the case. Had the Committee disregarded the case based on the non-State identity of the potential torturing entity, it would have resulted in a gap in human rights protection solely because the actors perpetrating the violations could not be held directly to the norms under international human rights treaties.

It is certainly an interesting outcome when compared to other cases heard by the Committee dealing with potential torturous acts being committed by

$281 \quad$ Ibid para. 3.1 and para. 6.5.

$282 \quad$ Ibid para. 3.1 and para. $5 \cdot 5$. 
other non-State armed groups, such as S.V. et al. v. Canada, in which the Committee took the approach of upholding the State's positive obligation to protect human rights. In that case, however, the relevant non-State armed group (the LTTE) did not have effective control over an area of territory within Sri Lanka, which had not itself failed as a State. The extreme rarity of the circumstances of a failed State in Elmi has indeed prevented the CteeAT from applying this kind of indirect horizontal effect again. Even in a subsequent case regarding extradition to Somalia of an individual who believed himself to be at a real risk of torture by a non-State armed group, the CteeAT distinguished the case on the grounds that Somalia had by then regained a State authority acting as central Government in the international community. ${ }^{283}$ The fact that the group in question still controlled a portion of Somalian territory was not considered enough to treat it as a State actor. Curiously, though, in a latter case concerning the LTTE, the CteeAT did consider that in cases where 'the non-governmental entity occupies and exercises governmental authority over the territory to which the complainant would be returned', it was not necessary to ascertain State consent or acquiescence in future acts of torture by that actor. ${ }^{284}$ The distinguishing factor for the Committee here seems to be whether the individual will be returned to the territory controlled by the LTTE. Further evidence that the CteeAT is not willing to broaden the application of Elmi to non-State actors more generally can be found in the case of V.X.N. and H.N.v. Sweden. The Committee explicitly stated that whether non-refoulement extends to a 'risk [of] pain or suffering inflicted by a private person, without the consent or acquiescence of the State, falls outside the scope of article $3 .{ }^{285}$

It is clear, then, that while the CteeAT will take a case-by-case approach, in general it is not actually willing to apply indirect horizontal effect beyond invoking States' consent or acquiescence.

4.4.3 Critical Remarks on the Jurisprudence of the Committee against Torture

The CteeAT has engaged to a considerable degree with the horizontal effect of human rights within the CAT. On the one hand, the definition of torture it has adopted through general comments and views on individual communications is broad, in that the CteeAT has understood it to include a positive obligation

\footnotetext{
283 H.M.H.I. v. Australia, CAT/A/57/44/177/2001 (1 May 2002), para. 6.4.

284 un CteeAT, S.S. v. The Netherlands, CAT/C/30/D/191/2001 (5 May 2003), para. 6.4.

285 V.X.N. and H.N. v. Sweden, СAT/A/55/44/130 and 131/1999 (15 May 2003), para. 13.8. This decision was further upheld in M.P.S. v. Australia, СAT/A/57/44/138/1999 (30 April 2002), para. $7 \cdot 4$.
} 
on States to protect individuals from torture by non-State actors. On the other hand, the Committee's application of the requirement that torture or inhuman or degrading treatment or punishment be done at least with the 'consent and acquiescence' of a State actor has so far been restricted to cases in which the State had concrete knowledge of a risk of an individual being subject to this treatment. While this appears stricter than the 'foreseeability' standard applied by the CteeEDAW, it could simply be due to the facts of the cases brought before the Committee.

In the case of Sadiq Shek Elmi v. Australia, the CteeAT has certainly shown that in extreme circumstances it is willing to go beyond an application of indirect horizontal effect through States' obligation to protect, to treat certain non-State actors as State actors to prevent torture. By no means, though, can this be considered a general rule for the Committee. The special circumstances of the case must be borne in mind. Specifically, the context of the failed State, the governmental authority being exercised by the non-State actor and the fact that it was not actually the non-State actor, but rather the State wishing to extradite the applicant, who was being held responsible for a potential violation of human rights. These circumstances considerably temper the possible significance of the decision.

\subsection{Committee on the Elimination of Racial Discrimination}

The Convention on the Elimination of Racial Discrimination (CERD) includes a potential exception to the vertical nature of the human rights obligations contained within it. ${ }^{286}$ This can be found in Article $5(\mathrm{e})$ of the Convention, which has been the subject of a brief General Recommendation (No. 20) by the Committee on the Elimination of Racial Discrimination (CteeERD). It is also interesting that reference to the positive obligations of State Parties to the Convention can be found in Article 4. This provision requires States to take 'immediate and positive measures designed to eradicate all incitement to, or acts of' racial discrimination. Significantly, reference is also made here to the possible exception of vertical obligations found in the Universal Declaration of Human Rights (UDHR), ${ }^{287}$ the principles embodied within this instrument having to be taken into account by States in the taking of the aforementioned

286 International Convention on the Elimination of All Forms of Racial Discrimination, (21 December 1965, entered into force 4 January 1969) United Nations Treaty Series, vol. 660, 195 (CERD).

287 UN General Assembly, Universal Declaration of Human Rights, 10 December 1948, 217 A (III). 
measures. ${ }^{288}$ Although no mention of a specific provision from the UDHR is given in Article 4, it can be inferred that the principles mentioned are those found in Article 29(2) ${ }^{289}$ - an inference made explicit by the CteeERD in its General Recommendation No. 15 on Article $4 .{ }^{290}$ The CteeERD's recommendations and jurisprudence dealing with potential horizontal effect of the Convention will now be assessed.

\subsubsection{General Recommendations of the Committee on the Elimination of Racial Discrimination}

As stated, Article 5 CERD was briefly discussed by the CteeERD in General Recommendation No. 20, with explicit reference to non-State actors. The recommendation seems to suggest that private actors themselves could be (partially) responsible for protecting the rights contained in Article 5 'and any similar rights'. The CteeERD states that 'protection may be achieved in different ways, be it by the use of public institutions or through the activities of private institutions. ${ }^{291}$ While this may emphasise the private actor's potential role in protecting human rights, the Committee does not go so far as to say that private institutions should actually be responsible for ensuring protection. Indeed, the CteeERD goes on to identify the obligation to ensure human rights protection as a State obligation, which covers the actions of private actors: where 'private institutions influence the exercise of rights ... the State party must ensure that the result has neither the purpose nor the effect of creating or perpetuating racial discrimination. ${ }^{292}$ In another recommendation, the CteeERD has reiterated the fact that States' obligation to protect human rights refers to the actions of non-State actors as well as public actors. In its General Recommendation No. 30 on the rights of non-citizens, the CteeERD identified such actors as including 'politicians, officials, educators and the media, on the Internet and

\footnotetext{
288 Article 4 CERD.

289 Article 29(2) UDHR provides: 'In the exercise of his rights and freedoms, everyone shall be subject only to such limitations as are determined by law solely for the purpose of securing due recognition and respect for the rights and freedoms of others and of meeting the just requirements of morality, public order and the general welfare in a democratic society.'

290 Committee on the Elimination of Racial Discrimination (CteeERD), 'General Recommendation 15: Organized violence based on ethnic origin (Art. 4)', 17 March 1993, contained in UN Doc. A/48/18, para. 4.

291 UN CteeERD, 'General Recommendation No. 20, The guarantee of human rights free from racial discrimination', 14 March 1996, para. 5 [emphasis added]. See also Clapham, Human Rights Obligations of Non-State Actors (n 18) 321.

292 Ibid.
} 
other electronic communications networks and in society at large, ${ }^{293}$ in relation to whom States must (again under their obligation to protect) take 'resolute action' to protect individuals from racial discrimination. ${ }^{294}$

Further inference to States' positive obligation to protect human rights from non-State actors is found in General Recommendation No. 15, dedicated to Article 4 of the Convention. ${ }^{295}$ The recommendation does not elaborate much on the meaning of the 'positive measures' mentioned in the article. Interestingly, General Recommendation No. 32 did elaborate on what kinds of measures States are obliged to take in this context, including, inter alia, the adoption of 'legislative, executive, administrative, budgetary and regulatory instruments. ${ }^{296}$ The underlying goal of Article 4 must be to protect individuals from propaganda involving racial discrimination by all actors (reflected in the requirement that States 'declare an offence punishable by law all dissemination of ideas based on racial superiority'). ${ }^{297}$ Nevertheless, there was no reference either in the Convention itself, or in the General Recommendation, to the obligation to protect, or to the due diligence duty of States. Indeed, the Recommendations only mention an investigative requirement of States in relation to the 'national law and its implementation'298 - inherently public matters. This seemingly rendered investigation into private acts outside of the scope of the positive measures to be taken unless this can be read into the implementation aspect. However, in a later General Recommendation also dealing with Article 4 (No. 35), the CteeERD suggested that obliging States to conduct such investigations could be read into the obligation that States make certain conduct 'punishable by law'. 299 This is because simply making certain conduct constitute a criminal offence is not sufficient without its effective

293 UN CteeERD, 'General Recommendation 30, on Discrimination Against Non-Citizens', 19 August 2004, CERD/C/64/Misc.11/Rev. 3, para. 12. See also Clapham, Human Rights Obligations of Non-State Actors (n 18) 322.

294 Ibid.

295 UN CteeERD, 'General Recommendation No. 15: The Right to Water (Arts. 11 and 12 of the Covenant)', 20 January 2003, E/C.12/2002/11.

296 UN CteeERD, 'General Recommendation 32, The meaning and scope of special measures in the International Convention on the Elimination of All Forms Racial Discrimination', 24 September 2009, CERD/C/GC/32, para. 32. Although this was stated in the context of 'special measures', the CteeERD referred to this when discussing Article 4 in a subsequent Recommendation. See Un CteeERD, 'General Recommendation 35, Combating racist hate speech', 26 September 2013, CERD/C/GC/35, para. 10.

297 Article 4(a) CERD.

298 Un CteeERD, 'General Recommendation No. 15' (n 295) para. 5 .

299 Un CteeERD, 'General Recommendation No. 35’ (n 296). 
implementation. ${ }^{300}$ This implementation, the CteeERD states, requires investigations of potential offences to be carried out, leading to prosecution when appropriate. ${ }^{301}$ Taken together with the wording of Article 4, the provision could be seen as reflecting (or being part of) a duty of due diligence to be fulfilled by State Parties.

This assertion is supported by a comparable obligation to that in Article 4, found in Article 3 CERD. This provision requires State Parties to 'prevent, prohibit and eradicate all practices of racial segregation'. In its General Recommendation No. 19, the CteeERD has read this as placing positive obligations on States, emphasising the possibility that partial segregation arise as an 'unintended by-product of private persons. ${ }^{302}$ The consequence of this - that racial segregation can occur 'without any initiative or direct involvement by the public authorities' 303 - prompted the CteeERD to recommend that States Parties monitor the kinds of situations that could lead to racial segregation. ${ }^{304}$ Again, despite no allusion to due diligence by the Convention or the CteeERD, this reflects very similar principles to those referred to by the other treaty bodies in their discussions of due diligence. It is curious that the CteeERD has chosen not to follow suit in using the same terminology as other treaty bodies, but this also shows that assumptions cannot necessarily be made as to the effect of bodies' decisions from the fact that they do not refer directly (or even indirectly) to the horizontal effect of the rights within their jurisdiction. To avoid speculating, it suffices to say that the CteeERD has in effect applied indirect horizontal effect by fleshing out States' positive obligations and making concrete recommendations as to how they could be fulfilled. These recommendations have, as they did with the other bodies discussed above, been restricted mostly to procedural obligations of States rather than laying down concrete standards against which to hold non-State actors (other than the general terms used). The question therefore remains whether the State should impose obligations or responsibilities at the national level holding non-State actors to the same standards as the State in terms of the substance/content of human rights.

\footnotetext{
300 Ibid para. 17 .

301 Ibid.

302 UN CteeERD, 'General Recommendation XIX on article 3 of the Convention', 18 August 1995, contained in UN Doc. A/50/18, para. 3 .

303 Ibid para. 4.

304 Ibid.
} 
Pursuant to Article 14 of the Convention on the Elimination of All Forms of Racial Discrimination the CteeERD can hear individual complaints from individuals regarding alleged violations of the Convention by States that have adopted a declaration accepting its competence to do so. The CteeERD has dealt with horizontal effect on quite a few occasions. This is to be expected, since racial discrimination is something that often happens in private relationships rather than by the State itself. Several examples will be focused on in the following discussion.

The CteeERD made several references to States' obligation to protect vis-àvis non-State actors in the case of L.K. v. The Netherlands. ${ }^{305}$ The applicant, a Moroccan citizen residing in the Netherlands was subject to verbal abuse and threats from a group of Dutch citizens who refused to accept him as a resident on their street, going so far as to sign a petition refusing his acceptance. The applicant complained to the police, who he alleged failed to conduct a thorough or complete investigation into the events. In its opinion, the CteeERD agreed with the applicant that the words and actions of the Dutch citizens constituted 'incitement to racial discrimination and to acts of violence against persons of another colour or ethnic origin' under Article 4 CERD, which the State had violated through its lack of an adequate investigation. ${ }^{306}$ In particular, the CteeERD stated that ' $[\mathrm{w}]$ hen threats of racial violence are made, especially when they are made in public and by a group, it is incumbent upon the State to investigate with due diligence and expedition. ${ }^{307}$ The explicit references to non-State actors and due diligence in the context of a State's obligation to protect human rights suggest an application of indirect horizontal effect by the CteeERD based on procedural obligations of the Dutch State (i.e. to investigate and punish non-State actors accused of racial discrimination). The reasoning of the CteeERD in this case mirrors that in its General Recommendations on Article 4, discussed above.

The obligation of States to conduct a thorough investigation into instances of racial discrimination by non-State actors was also discussed in the case of Habassi v. Denmark. ${ }^{308}$ The author of the complaint, a Tunisian man with

305 UN CteeERD, L.K. v. The Netherlands, Communication No. 4/1991, Un Doc. A/48/18 at 131 (1993).

$306 \quad$ Ibid para. 6.3.

307 Ibid para. 6.6.

308 UN CteeERD, Habassi v. Denmark, Communication No. 10/1997, CERD/C/54/D/10/1997 (1997). 
permanent residence in Denmark, had applied for a loan from a private bank, which required him ('motivated by the need to ensure that the loan was repaid'309) to provide evidence of his Danish nationality before approving the loan (after previously stating that they would accept loan requests from individuals with permanent residence). After his loan application was rejected, with the help of an antidiscrimination organisation the applicant complained to the Danish police, who did not pursue an investigation. The State's argument was that there was insufficient evidence that an unlawful act had taken place. The CteeERD, however, agreed with the applicant that a human rights violation had occurred. It based its decision on the need for States to investigate whether or not racial discrimination had occurred (whether directly or indirectly), which requires a 'proper investigation' into the facts. ${ }^{310}$ Here, the basis upon which the bank required an individual to prove Danish nationality before granting a loan was in question - although nationality is not an issue of racial discrimination as such, it may have an unintended, indirect effect of racial discrimination. ${ }^{311}$ Since the police had accepted the bank's reasons on face value and had not conducted such an investigation, it was found to be in violation of Article 6 CERD (the right to an effective remedy) in connection with Article 2(d) (the definition of racial discrimination). The case therefore goes quite far in requiring States to protect individuals from non-State actors (albeit focusing on procedural requirements). A very similar reasoning and findings were applied by the CteeERD in its opinion on Kashif Ahmad v. Denmark. ${ }^{312}$ In this case, the applicant alleged that he had been racially discriminated against by a teacher and a headmaster of a school, on school property. He complained that the Danish authorities refused to prosecute the individuals or conduct a thorough investigation into what happened. After a cursory investigation into the facts, the authorities stated that the offensive statements made to the applicant fell outside of the scope of Danish criminal law, and that the applicant could only seek redress through civil law - a finding that the applicant was unable to appeal. ${ }^{313}$ The CteeERD opined that had a thorough investigation been undertaken, the authorities would have been able to establish whether the applicant was subject to racial discrimination within the meaning of Article 2(1)(d) CERD. ${ }^{314}$ The CteeERD ultimately found that because of the

309 Ibid 9.3.

310 Ibid. See also Clapham, Human Rights Obligations of Non-State Actors (n 18) 319-320.

311 Ibid.

312 UN CteeERD, Kashif Ahmadv. Denmark, CERD/C/56/D/16/1999 (2000).

313 Ibid para. 4.6.

314 Ibid para. 6.2. 
lack of investigation and ability of the applicant to find out whether his rights had been violated at the national level, the State had failed to effectively protect him from racial discrimination. ${ }^{315}$

As well as an obligation to investigate instances of racial discrimination by private actors (in a timely manner), the CteeERD has made recommendations that States 'complete' their legislation protecting individuals from racial discrimination by private actors. In the case of Lacko v. Slovakia, for example, the Committee recommended such legislative action to 'guarantee the right of access to public places in conformity with article 5 (f) of the Convention and to sanction the refusal of access to such places for reason of racial discrimination. ${ }^{316}$ The case had involved a Romani individual being refused service in a restaurant at a railway station on the basis that he was Romani. The State investigated the situation and prosecuted the culprit, which led the CteeERD to find no violation of the Convention. However, it did not refrain from giving this extra counsel to Slovakia to strengthen its performance of the duty of due diligence. ${ }^{317}$

\subsubsection{Critical Remarks on the Jurisprudence of the Committee on the Elimination of Racial Discrimination}

In light of the specific references made within the CERD to various non-State actors, the CteeERD has not actually gone very far in applying the Convention horizontally. This is odd in light of the mention of private actors in the Convention itself - the clear obligation to protect individuals from racial discrimination in the private, as well as in the public sphere could seem to render further consideration of private actors even more necessary. However, it could also be said that there are not as many substantive human rights contained in the CERD that could be upheld vis-à-vis non-State actors, other than those in Articles 4 and 5 . Most of the cases that involved a non-State actor found violations of the State of these two provisions, as well as Article 6 which provides the right to effective remedy. Taken together, the clear obligation to conduct thorough investigations into alleged incidents of racial discrimination by private parties, and the obligation to have a legal framework in place to punish such parties when found responsible, strongly reflect at least two elements generally considered to constitute a duty of due diligence (together with the duty

315 A similar finding was made in Un CteeERD, Mohammed Hassan Gelle v. Denmark, Communication No. 34/2004 (2006).

316 UN CteeERD, Lacko v. Slovakia. Communication No. 11/1998 (2001), para. 11.

317 The UN CteeERD also suggested that Slovakia 'take the necessary measures to ensure that the procedure for the investigation of violations is not unduly prolonged': ibid. 
to prevent interference by non-State actors). Indeed, the CteeERD has made explicit reference to this duty, although not on a regular basis.

\section{Reflections on the Horizontal Effect of International Human Rights in International Jurisprudence}

The above discussions show widespread and varied acknowledgements of the considerable role that non-State actors have to play in the enjoyment of human rights. While the international legal framework does not allow for nonState actors to be directly burdened with international legal obligations, the UN human rights treaty monitoring bodies have on many occasions upheld the standards within international human rights law against the actions of non-State actors. This has been achieved by the Committees mainly in two identifiable ways, which will be discussed below. The first, and most common approach, is through the invocation of States' positive obligation to protect human rights from third parties. As repeatedly observed in the analysis, the vast majority of recommendations made by the monitoring bodies concern procedural obligations and explanations of the kind of action that States must take (legal, regulatory, administrative, judicial, etc.) rather than mentioning whether the standards applicable to non-State actors should be assumed to be the same as those applied to States (which are themselves further developed through other general comments and jurisprudence of the bodies). In this sense, it could be said that the analysis is more useful in terms of laying down the content of States' obligation to protect human rights vis-à-vis different actors and in different situational contexts. The focus could show either a reluctance on behalf of the bodies to address standards (albeit national ones) for non-State actors more directly, perhaps an opinion that a distinction between State and non-State standards is irrelevant, or that it should simply be assumed that the concrete standards for non-State actors at the national level are the same substantive standards for States at the international level.

\section{1}

\section{The Types of Indirect Horizontal Effect Identified}

The requirements of the obligation to protect seem to differ somewhat depending on what kind of non-State actor has interfered with the enjoyment of human rights; the nature of the actor and the relationship they have with the victim of human rights violations appears to be a factor in the way in which monitoring bodies apply indirect horizontal effect. For the remainder of this article, this first approach will be named 'pure indirect horizontal effect', to denote what is quite a clear-cut method of attributing the harmful effects 
of non-State actors to States. The second approach, which is very tentatively taken by the monitoring bodies, also appears to depend on the kind of actor (and the kind of actions being taken by that actor). For the purposes of this article, the second approach will be labelled 'categorical indirect horizontal effect'. Essentially, it refers to cases in which human rights laws are being applied against what is technically a private actor who is being treated, for the particular instance at hand, as a special kind of public actor', or a 'quasi-public actor'. In other words, the private actor is being re-categorised for the purposes of ensuring broader protection of international human rights. The following sections critically discuss the two approaches and the instances in/extent to which they are applied.

\subsection{1 'Pure' Indirect Horizontal Effect}

As explained, pure indirect horizontal effect holds States responsible for the actions of non-State actors by invoking the State's obligation to protect human rights. There is a limited degree to which this approach can actually be said to be a form of horizontal effect, given its focus on State obligations. However, when States follow the advice of the monitoring bodies under this approach, it creates an indirect obligation for non-State actors (or imposes a certain standard of behaviour) at the international level, having first resulted in a direct standard of behaviour being imposed on the non-State actor at the national level (whether through legal, administrative or other means).

The analysis above shows that 'pure' indirect horizontal effect is consistently applied by the different monitoring bodies, but is sometimes expressed in different manners. One of the main tenets of the obligation, applied by all of the bodies, is an obligation to take legal, administrative or other appropriate measures to protect individuals from non-State actors - to adopt an appropriate framework within the State capable of preventing, investigating and punishing instances of non-State actor interference with human rights. In other words, the monitoring bodies uphold the standards of due diligence. This has not been made explicit by each of the bodies every time that they appear to apply the obligation (especially for the CteeESCR) although the actual standards upheld do appear to be consistent.

The obligation of due diligence has often been applied when the non-State actor interfering with human rights operates in the purely private sphere. This is particularly true of those monitoring bodies dealing with issues of discrimination (i.e. the CteeEDAW and CteeERD), which very commonly occurs in purely private relationships between two individuals. As explained in Section 3.3.1, the duty is one of conduct, rather than result. This has led the monitoring bodies to take an approach of listing possible action to be taken 
in their general comments, although it is not possible to create an exhaustive checklist of protective measures to be taken to combat every circumstance of human rights interference. The general comments have by now provided quite an extensive array of measures that States should be taking in different subject-areas (e.g. regarding employment, or the provision of services) or in relation to specific rights within their respective conventions.

As well as the duty of due diligence (or perhaps even part of it, as the bodies' practice is not clear on this point), the obligation to protect includes an obligation to regulate private actors. This has been upheld by each of the monitoring bodies except for the CteeAT, and is particularly elucidated in the context of privatisation or the delegation of 'public' tasks to non-State actors, as well as in the 'quasi-public sphere' such as employment.

What is less clear about the interpretation and application of human rights by the monitoring bodies is to what extent the bodies actually engage with the concept of attribution, at least from the perspective of State responsibility within international law. Although some of the bodies have mentioned that non-State actors' conduct can be attributed to the State, with the exception of the CteeESCR in its general comment on business and human rights, none of the bodies have explicitly engaged with the International Law Commission's DASR. ${ }^{318}$ This begs the question whether the monitoring bodies view 'attribution' as simply another word for describing the way in which the obligation to protect works in practice, thus enabling the 'attribution' of non-State conduct to States in the situations where the obligation to protect has not been fulfilled. If so, the language used could create confusion amongst international law scholars, aggravated by the explicit reference to DASR in the CteeESCR's General Comment No. 24.

\subsubsection{Categorical Indirect Horizontal Effect}

Categorical indirect horizontal effect is the second type that can be identified. This refers to cases in which human rights laws are being applied against what is technically a private actor who is being treated, for the particular instance at hand, as a special kind of public actor', or a 'quasi-public actor'. At first sight, this may appear similar to direct horizontal effect, in that it is a private actor that would be 'violating' a human right. However, the fact that the responsible non-State actor is deemed to be a public actor in the particular circumstances of the case would allow a case to be brought against the (re-categorised)

318 Of course, this would only be possible in their practice after the publication of the DASR in 2001, but is still striking in light of the importance the DASR have now gained in international law. 
non-State actor. For the international level, this approach does remain more theoretical than at the national level (e.g. in the United Kingdom), ${ }^{319}$ as it has still not allowed a full case to be brought against a non-State actor, given the constraints of the human rights treaty framework. Nonetheless, it has been dealt with and taken to a limited extent by the CteeAT.

The CteeAT applied 'categorical' indirect horizontal effect in relation to non-State armed groups. Given the nature of the groups and the fact that they are usually engaged in an armed conflict with the State in a particular territory, the public functions that they carry out are not delegated from a 'pure' public authority, unlike in some of the other cases discussed above. Instead, the groups take up the responsibility for carrying out the public functions of their own accord. Crucially, in the case of Sadiq Shek Elmi v. Australia where the CteeAT seems to apply this approach, the State was no longer a relevant player - Somalia had failed as a State, which had led to quasi-public authorities taking over traditionally State functions and exercising effective control over 'State' territories. The case is admittedly of limited value, because of the particular situation of non-refoulement and the case's weak precedential value, as explained above. Nonetheless, it opens the door for future general comments and case law to apply a similar approach. This was arguably done by the CteeEDAW in its General Recommendation No. 30.

So far, the limited application of this approach (in terms of number of cases and in relation to which actors it has been applied) makes it difficult to see where the threshold lies for re-categorising a non-State actor as a 'public' actor and holding them to international standards (at the international level).

\subsection{The Treatment of Different Actors}

First, the bodies, both in their general comments and views on individual communications, have upheld States' obligation to protect individuals from harmful acts by other individuals. This would include, for example, other family members (e.g. CteeEDAW General Recommendation No. 19; A.T. v. Hungary), neighbours (e.g. L.K. v. The Netherlands), and employers (e.g. CteeESCR

319 In the United Kingdom, Section 6(3)(b) of the Human Rights Act 1998 allows cases to be brought against non-State actors that are carrying out public functions, treating them as a kind of hybrid public authority. Although the UK's courts have been ambivalent in their application of the provision, there have been cases in which private actors have been treated as public authorities for the purposes of human rights protection, e.g. Aston Cantlow and Wilmcote with Billesley Parochial Church Council v. Wallbank and another, House of Lords [2003] U KHL 37. See for discussion, Hallo de Wolf, Reconciling Privatization with Human Rights (n 18) 289-303. 
General Comment Nos. 5 and 14). In cases where such actors were involved, the focus of the treaty bodies was mostly on due diligence obligations of the State. An emphasis has certainly been placed on the obligations to investigate interference with human rights by non-State actors, as well as to prevent and punish the actions, especially where the State is aware of a risk to the individual. In one sense, the cases show a stronger application of horizontal effect, as the relationships between the individuals is often exclusively in the private sphere (e.g. between spouses). However, the actions of the non-State actors themselves are not the subject of much discussion by the Committees, except to the extent that they show that a particular right is engaged. Rather, the focus is (as it should be, according to the international human rights law framework) on the action or inaction of States either to prevent the harm occurring, or in reaction to the harm that occurred, which allows the private actor's conduct to be attributed to the State. Interestingly, because of the wording of Article 1 CAT requiring at least the 'consent or acquiescence' of the State for an act to fall within the scope of the Convention against Torture, the CteeAT has seemed to take a strict stance as to when acts of torture by private actors can lead to a violation of the Convention. It seems to be that only when the State knew of a risk of torture would the actions be imputable to the State. This contrasts with the approach suggested by CteeEDAW in Angela González Carreño v. Spain and the approach of other bodies with jurisdiction over the prohibition of torture, which are comparatively broader.

Second, the treaty bodies have applied States' positive obligation to protect human rights from private businesses (CteeESCR General Comment Nos. 5 and 12) and entities such as banks (e.g. Habassi v. Denmark) and insurance boards (e.g. B.d.B. v. The Netherlands). The horizontal effect here is very similar to that found in the jurisprudence concerning relationships between individuals.

Third, the treaty bodies have applied indirect horizontal effect in relation to private companies or institutions that are carrying out public functions that have been delegated to them by the State. This category of actor has included, for example, privately run prisons (e.g. Cabal and Pasini v. Australia) and private healthcare institutions (e.g. Alyne da Silva Pimentel Teixeira (deceased) $v$. Brazil). In their discussions of these actors, the treaty bodies have focused on attributing the actions of the non-State actors to the State because of the public nature of the functions that the actors are carrying out and because they were delegated these activities by the State. Here, the main argument appears to be that States cannot give up their own international responsibility by delegating certain functions to non-State actors. The treaty bodies have upheld (within the obligation to protect) an obligation to regulate and supervise the privatised companies, using a failure to do so as the basis for a State violation 
of a particular right. As well as the obligation to regulate, the treaty bodies have also applied the duty of due diligence to these actors (indeed, it appears to be applied in some form in relation to every kind of actor).

Fourthly, cases of indirect horizontal effect have also occurred where the actor interfering with human rights is a non-State armed group. Here, the Committee against Torture has taken different approaches to horizontal effect. In the case of S.V. et al. v. Canada, the State's obligation to protect was upheld. In Sadiq Shek Elmi v. Australia, though, the approach taken was to treat the non-State actor as a State actor. This seems only to apply when the group as effective control over the area of land to which an individual is going to be extradited, and/or when there is no effective central State authority within the receiving State. In these cases, it does not appear that there actually has to be any attribution to the State. The CteeEDAW has also dealt with these actors in General Recommendation No. 30, stating non-State armed groups' obligation to respect human rights during armed conflict (also placing emphasis on those groups with effective control over an area of territory).

Fifthly, suggestions have been made, at least by the CteeESCR (General Comment Nos. 14 and 15), that international organisations may have human rights obligations. This would in theory be an example of direct horizontal effect, but there was no legal basis provided by the CteeESCR and there are no examples of treaty bodies applying human rights treaties to international organisations in individual communications. The obligations could therefore be read as being moral, but not yet legal, in nature.

It is possible to conclude that the vast majority of the jurisprudence of the UN human rights treaty bodies involves a connection being made between the State and the private actor concerned. The basis on which to make this connection and attribute the private acts to the State differs slightly between different bodies and depending on the non-State actor involved. The bases remain significantly limited by the current international legal framework. So far, with the exception of the unique case of Sadiq Shek Elmiv. Australia (which, it must be remembered, did not actually apply the Convention obligations to a non-State actor), treaty bodies seem reluctant to push the boundaries too far, at least in their views on individual communications, in which they are careful to invoke a legitimate legal basis. In order to fill gaps in human rights protection arising from situations falling outside of the State's obligation to protect human rights, either the international human rights framework will have to evolve to cover certain non-State actors, or ways of protecting individuals outside of the confines of the legal framework will have to be strengthened.

Overall, in relation to the kinds of actors that are treated differently, perhaps what is not present in the documents analysed is more telling than what 
is - the application of the law seems to allow protection from individuals, and from private companies, especially privatised ones, but there are some nonState actors that fall (sometimes completely) out of the mix. The more 'public' non-State armed groups and international organisations have been dealt with to a limited degree, which has been particularly significant for the potential direct horizontal effect of human rights. Their treatment has been more direct within general comments, whilst in views on individual communications it has at most been said that these actors could be capable of violating human rights, or have responsibilities to help States in the implementation of their rights.

\subsection{Critical Reflections on the Treaty Bodies' Reasoning}

Before drawing conclusions on the application of horizontal effect by the treaty bodies examined, a few comments on the bodies' reasoning will be made. Although it did not form part of the research of this article per se and will thus not be discussed in detail, it was very interesting to see how the Committees made their decisions in relation to individual complaints, and how they framed their comments in general recommendations and comments. The following comments are made only in relation to the practice included in the analysis, and should not be read as applying to the practice of the treaty bodies generally. ${ }^{320}$

Each of the five bodies regularly relied upon their own previous practice, both in general comments and views on individual communications. They did refer to each other's practice as well, although not particularly often. ${ }^{321}$ The analysis nonetheless showed that at least in relation to those aspects of the bodies' practice relating to horizontal effect, the interpretations of the bodies have converged to a large extent (notwithstanding the inconsistencies in the use of language).

They also regularly mentioned other international treaties in general comments (particularly the other 'core' human rights treaties) as well as, to a lesser degree, the output of international organisations, particularly UN agencies and

320 For an in-depth discussion of interpretation by the human rights treaty bodies more generally, see B. Schlütter, 'Aspects of human rights interpretation by the un treaty bodies', in: H. Keller and G. Ulfstein (eds) UN Human Rights Treaty Bodies: Law and Legitimacy (Cambridge: Cambridge University Press, 2012) 261.

321 This can be presumed on some occasions to be because of timing - the HRCtee's general comment on torture, for example, predated the practice of the CteeAT, and so could not have considered it. The CteeESCR however, has been more forthcoming in referring to other bodies' work, and also referred extensively to the work of the International Labor Organization in the context of the right to work. See CteeESCR, 'General Comment No. 23' (n 180). 
subsidiary organs. However, it was striking to see how rarely most of the bodies relied on sources of international law other than international treaties when interpreting the human rights treaties. ${ }^{322}$ Indeed, even in instances where one of the parties to an individual communication relied upon the jurisprudence of judicial bodies (e.g. the European Court of Human Rights) or customary international law, the treaty bodies most often declined to mention the sources in their own reasoning. ${ }^{323}$ It was very rare indeed that a treaty body referred to customary international law. Although several references were made, ${ }^{324}$ on most occasions the reference was simply to the fact that as well as being bound by the relevant treaty, States were also bound by customary international law that covered the same material. An exception to this was the CteeESCR's General Comment No. 24, which referred more substantively to customary international law, ${ }^{325}$ as well as to the DASR, ${ }^{326}$ which have customary status. In fact, in both its general comments and views on individual communications, the CteeESCR consistently took into account a broader range of sources than the other treaty bodies. ${ }^{327}$ Perhaps General Comment No. 24 will prove to be part of a broader trend to take into account other sources of law, although it does not seem as though the other bodies have considerably altered their approach to this over the years.

Overall, as also suggested by the previous comments in relation to attribution and the DASR, the reasoning of the human rights treaty monitoring bodies in the practice analysed was sometimes lacking in terms of grounding outcomes in a legal basis. While the treaties being applied were always discussed, the legal reasoning which led to a particular interpretation of the provisions was sometimes extremely minimal. For example, it is unclear whether the

322 The primary and secondary sources of international law are listed in Article 38 Statute of the International Court of Justice, 18 April 1946. The bodies regularly noted other relevant international treaties, particularly other 'core' human rights treaties but also International Labor Organization Conventions.

323 This occurred in, for example, Sadiq Shek Elmi v. Australia (n 278); and Hajrizi Dzemajl et al. v. Serbia and Montenegro (n 274).

324 See e.g. Un CteeESCR, 'General Comment No. 24' (n 191); CteeEDAW, 'General Recommendation No. 28' (n 207); CteeAT, 'General Comment No. 2' (n 256).

325 The CteeESCR stated that '[c]ustomary international law also prohibits a State from allowing its territory to be used to cause damage on the territory of another State.' CteeESCR, 'General Comment No. 24' (n 191) para. 27.

326 Ibid paras. 11,29 and 32.

327 This is particularly true of its most recent general comment, which also considered national case law, decisions of ICSID and soft-law principles such as the Maastricht Principles on Extraterritorial Obligations. See ibid. 
treaty bodies follow the Vienna Convention on the Law of Treaties' rules on interpretation - something that has been discussed more generally. ${ }^{328}$ This may cause problems concerning the legitimacy of the bodies' jurisprudence and the willingness of States to implement changes pursuant to general comments and/or views, both of which have already been called into question. ${ }^{329}$

In turn, such problems may affect the role and impact of the treaty bodies within international law more generally, as well as their place within the community of international courts, tribunals and other adjudicatory bodies. These aspects should also be considered when looking at the significance of the treaty bodies' practice for what concerns the horizontal effect of human rights. It is important to remember, for example, that unlike other human rights adjudicatory bodies such as the European Court of Human Rights, the treaty bodies do not have binding authority. ${ }^{330}$ Nonetheless, their practice has been relied upon by binding regional and international adjudicatory bodies (e.g. the European Court of Human Rights, the Inter-American Court of Human Rights and the International Criminal Tribunals for the Former Yugoslavia and Rwanda, respectively), ${ }^{331}$ although to a lesser degree than by other non-binding bodies (the Inter-American Commission on human Rights, for Example, has referred

328 See e.g. K. Mechlem, 'Treaty Bodies and the Interpretation of Human Rights', Vanderbilt Journal of International Law 40 (2009) 905; G. Ulfstein, 'Individual Complaints' (n 29). On reform of the treaty bodies system more generally, see e.g. M. O'Flaherty, 'Reform of the un Human Rights Treaty Body System: Locating the Dublin Statement', Human Rights Law Review 10(2) (2010) 319 .

329 Mechlem, 'Treaty Bodies and the Interpretation of Human Rights' ( $\mathrm{n} 328$ ).

330 They have nonetheless had a considerable impact on the development of international human rights law at the national level. See International Law Association Committee on International Human Rights Law and Practice, 'Berlin Conference Report' (n 24) which provides many examples of national courts relying on the practice of the bodies. See also K.J. McCall-Smith, 'Interpreting International Human Rights Standards: Treaty Body General Comments as a Chisel or a Hammer', in: S. Lagoutte, T. Gammeltoft-Hansen and J. Cerone (eds) Tracing the Roles of Soft Law in Human Rights (Oxford: Oxford University Press, 2016) 25. The willingness of national courts to do this is by no means mirrored in the reaction of States to the bodies' views on individual communications in which they were party; compliance by States with views on individual communications has been notoriously low. See, also for a discussion of the legal status of treaty bodies' decisions in national law, R. van Alebeek and A. Nollkaemper, 'The legal status of decisions by human rights treaty bodies in national law', in: H. Keller and G. Ulfstein (eds) UN Human Rights Treaty Bodies: Law and Legitimacy (Cambridge: Cambridge University Press, 2012) 356.

331 For a discussion of references to the practice of the UN human rights treaty monitoring bodies by binding adjudicatory bodies, see International Law Association Committee on International Human Rights Law and Practice, 'Berlin Conference Report' (n 24). 
to the practice on many occasions). Together with the prevalent reference to the practice of treaty bodies in the national context (both in jurisprudence and in the development of new legislation), this gives the findings of the bodies more significance than may be initially expected; the practice may not constitute formal (international) law, but certainly constitutes important guidance for those bodies (whether national, regional or international) that are able to make binding decisions on the same or related matters.

Bearing this in mind, it is a shame that the treaty bodies are not more candid in their reasoning, which currently makes it harder to evaluate whether or not they do justice to the topic of non-State actors and human rights. In particular, a lack of precise explanation of the legal bases for conclusions within general comments (although this may be changing) sometimes obscures the Committees' views on horizontal effect. This could be clarified through more reference to and engagement with rules and sources of international law and theories of horizontal effect in those instances where the Committees do indeed apply it, as well as more consistent use of terminology. As it stands, the Committees very rarely actually consider 'horizontal effect' as a concept, preferring to move directly to the practical measures that should be taken by (predominantly) States to protect human rights. That being said, the bodies have applied horizontal effect to the extent that their mandates and the international legal framework allow. In this respect, the findings of the analysis fit within the prevalent approach in legal science towards horizontal effect - that within the international legal framework as it is, there is no possibility of direct horizontal effect. The findings do not, however, seem to fit within new theories of horizontal effect being developed in literature (e.g. by Kanalan, discussed briefly in Section 3.2). However, the adoption and content of General Comment No. 24 regarding business activities suggests that at least the CteeESCR is willing to keep pace with the international community as it moves towards the elaboration of duties and obligations for business enterprises.

\section{Conclusion}

This article has conducted an in-depth analysis into whether and how five UN human rights treaty monitoring bodies deal with situations in which the direct cause of a human rights violation is a non-State actor. The analysis was conducted according to the framework of direct and indirect horizontal effect of human rights and in consideration of the confines of the current framework of international human rights law. 
It was found that the bodies are still looking mostly at various aspects of States' positive obligation to protect human rights, which sometimes enables the bodies to attribute the conduct of non-State actors to the State. The current international human rights law framework prevents non-State actors from being dealt with directly at the international level, allowing only States to have direct international obligations. Although with one exception the monitoring bodies themselves do not actually refer to the 'horizontal effect' of human rights, their interpretations and applications of treaties clearly acknowledge, on many occasions, the fact that situations of human rights violations can be caused by actions of private actors as well as States. On some (much more limited) occasions the monitoring bodies have explicitly acknowledged a more significant and perhaps even positive role for non-State actors within international human rights law.

The first type of indirect horizontal effect identified in the general comments and the jurisprudence of the monitoring bodies is 'pure' indirect horizontal effect - the application of States' positive obligation to protect human rights from the harmful actions of non-State actors, according to the tripartite typology of human rights. As noted above, this approach has been taken by each of the bodies in relation to a variety of non-State actors. It can generally be considered to consist of an obligation of due diligence, including a specific obligation to regulate, vis-à-vis the conduct of non-State actors. This is an obligation of conduct, meaning that the focus is on the types of action that States take at the national level to prevent, investigate, punish and provide redress for human rights violations caused by non-State actors. For this reason, the requirements and recommendations laid out by the Committees are mostly procedural, rather than explaining the concrete human rights standards which apply to non-State actors at the national level.

The second approach identified was 'categorical' indirect horizontal effect, under which non-State actors carrying out particular public functions normally undertaken by the State and having effective control over a certain area of territory are 're-categorised' or 're-classified' as public actors for the purposes of a specific situation. This provides extra protection for individuals in situations where the State may fulfil its obligation of conduct under the obligation to protect, but remains in a position where it is unable to provide de facto protection. So far, this has only been applied by the CteeAT (and arguably also CteeEDAW) and in relation to non-State armed groups.

In light of the non-binding nature of the documents analysed and the current international legal framework, we still cannot actually say that non-State actors currently have any binding obligations concerning human rights at the international level. However, the analysis shows that monitoring bodies are 
certainly engaging with the impact and effect that non-State actors have on human rights. To a more limited degree, they are also engaging with the prospect of direct responsibilities of non-State actors.

\section{Acknowledgements}

Lottie Lane, LLM is a Ph.D. Candidate at the Endowed Chair, Groningen Centre for Law and Governance. Her Ph.D. research focuses on the horizontal effect of international human rights law from a law and governance perspective. The author would like to thank Marlies Hesselman and the two anonymous reviewers for their extremely helpful comments and suggestions. 